Article

\title{
Inorganic and Organic Amendments Affect Soil Fertility, Nutrition, Photosystem II Activity, and Fruit Weight and May Enhance the Sustainability of Solanum lycopersicon L. (cv. 'Mountain Fresh') Crop
}

\author{
Theocharis Chatzistathis ${ }^{1, *}$, Vasileios Tzanakakis ${ }^{1,2}$, Anastasia Giannakoula ${ }^{3}$ and \\ Polyxeni Psoma ${ }^{1}$ \\ 1 Hellenic Agricultural Organization (H.A.O.) 'Demeter', Institute of Soil and Water Resources, Thermi, \\ 57001 Thessaloniki, Greece; vtzanakakis@hmu.gr (V.T.); p.psoma@swri.gr (P.P.) \\ 2 School of Agricultural Technology, Hellenic Mediterranean University, 71410 Crete, Greece \\ 3 Department of Agriculture, International University of Greece, 54700 Thessaloniki, Greece; \\ agianna@cp.teithe.gr \\ * Correspondence: t.chatzistathis@swri.gr
}

Received: 8 October 2020; Accepted: 23 October 2020; Published: 30 October 2020

\begin{abstract}
One of the most important issues for modern agriculture is how to decrease fertilization rates and enhance the sustainability of crops, without decreasing yields. Two inorganic (zeolite-zeo; vermiculite-ver) amendments and their mixtures with an organic soil amendment (goat manure) (i.e., zeo + ver, manure + ver, manure + zeo) were tested, and compared to the application of a controlled release fertilizer (CRF), in order to investigate if they were able to satisfy the nutritional needs of Solanum lycopersicon L. plants. For this purpose, a 112-day pot experiment was performed. After zeo and manure application, exchangeable $\mathrm{K}$ was increased from 16.5 times to 37.5 times. At the end of the experiment, total plant biomass was significantly higher in the CRF treatment, compared to the ver treatments (ver, ver + manure). Leaf $\mathrm{K}$ concentration was significantly higher in the zeo treatment $(5.93 \% \mathrm{dw})$, compared to those determined in the CRF, ver, and ver + manure. In contrast, significantly higher foliar $\mathrm{N}$ was found in the CRF $(4.83 \% \mathrm{dw})$ and zeo + ver $(4.24 \% \mathrm{dw})$ treatments, compared to manure + ver. Finally, photosystem II (PSII) activity was significantly higher in ver, and this was ascribed to the optimum foliar Mn found in this treatment (138 $\mathrm{mg} \mathrm{kg}^{-1} \mathrm{dw}$ ). It is expected that these data will provide a thorough insight towards decreasing chemical fertilization inputs and enhancing the sustainability of Solanum lycopersicon L. crop.
\end{abstract}

Keywords: zeolite; vermiculite; manure; controlled release fertilizer (CRF), fertilization; chlorophyll fluorescence

\section{Introduction}

Modern agriculture focuses on the necessity to increase crop productivity, without increasing (or even by decreasing) mineral fertilization rates in soils [1]. Natural or synthetic inorganic amendments have been used in agriculture as a tool to: (i) improve soil properties; (ii) enhance crop productivity; (iii) restore/remediate polluted, saline, and acid soils and decrease metal uptake; (iv) reduce the potential environmental and climate impacts arising from excessive nutrient availability (mainly $\mathrm{N}$ and $\mathrm{P}$ ) in soil [2-7]. Zeolites, which are among the most common inorganic amendments, are suitable for decreasing nutrient leaching, thus having beneficial and ecological effects $[8,9]$.

The high $\mathrm{NH}_{4}{ }^{+}$adsorption capacity of zeolite is of particular importance in agricultural soils receiving high amounts of $\mathrm{N}$ fertilization, which may regulate ammonia release and, therefore, 
nitrification activity, $\mathrm{N}$ availability to crops, and $\mathrm{N}$ losses to the environment (either in the form of nitrates or in the aerial forms $\mathrm{NH}_{3}$ or $\mathrm{N}_{2} \mathrm{O}$ ). Indeed, certain benefits from the combined use of $\mathrm{N}$ (organic or inorganic) and zeolite have been recorded, indicating higher $\mathrm{N}$ uptake, crop growth, and yields [10-12]; enhanced $N$ use efficiency $[13,14]$; and low $N$ losses via nitrate leaching $[14,15]$ or via denitrification/volatilization processes $[12,16]$.

Apart from the effect of zeolite on soil $\mathrm{N}$ availability, zeolite has been found to influence other nutrients' availability (mainly exchangeable cations, such as K), due to its inherent adsorptive properties and high nutrient (especially K) content [17,18], which significantly influences soil fertility and crop nutrition [5,19]. According to Gholamhoseini et al. [20], the addition of zeolite to composted manure decreased P leaching, probably reflecting the zeolite's high adsorption capacity. Besides its effects on nutrient availability, zeolite has also been used for other agricultural purposes; according to Eroglu et al. [21], more than 40 naturally occurring zeolites have been used: recent findings have supported their role in stored pest management as inert dust applications, pesticide and fertilizer carriers, soil amendments, animal feed additives, mycotoxin binders, and food packaging materials. It was also found that natural zeolite, together with symbiotic microorganisms, showed a positive effect on the root growth of olive plants, as well as on olive cuttings' rooting [22]. In addition, zeolite, in a mixture with perlite or other materials, has been used as a soilless growing medium for gerbera under alkaline stress conditions [23].

Vermiculite is a clay-type material found in nature; its magnesium form consists of two layers of silicon tetrahedra, in which silicon is partially replaced by aluminum, and a layer of $\mathrm{OH}-$ groups and magnesium ions, which form a strongly bound mica stack [24]. Due to its nature, vermiculite, as zeolite, has been a subject of investigation in soil-based or composting systems focusing mainly on vermiculite's effect on $\mathrm{NH}_{4}{ }^{+}$and/or nutrient availability (e.g., $\mathrm{P}, \mathrm{K}$, and $\mathrm{Mg}$ ) [6,25], on rate of metal adsorption [24], and on decrease in $\mathrm{N}$ emissions, in the form of ammonia [26,27] or $\mathrm{N}_{2} \mathrm{O}$ [26]. However, there is much less information available due to the limited number of studies; thus, the unanswered questions regarding the fate on nutrients and potential effects on soil processes still remain.

Despite the agronomic uses of zeolite and vermiculite, a few things are known with regard to their use and ability to support crop nutrition (instead of using chemical fertilizers or in combinational application with other inorganic/organic fertilizers, in terms of decreasing their excessive rates), sustain yields, and promote sustainability. Glisic et al., (2009) [2], who compared (in a two-year study) the treatments (i) NPK + manure and (ii) zeolite + manure on soil properties, in strawberry and blackberry crops, found that similar yields for both species were obtained between the two treatments, i.e., zeolite produced similar agronomic effects as the inorganic fertilizer 15-15-15. However, in their study, no plant nutrition data (foliar nutrient concentrations, nutrient uptake) were included. Aainaa et al. [28] studied the ability of clinoptilolite zeolite (CZ) to act as a supplementary fertilizer (together with mineral $\mathrm{P}$ fertilizers) for Zea mays L. and found that CZ inclusion in the fertilization program was beneficial, in terms of reducing excessive use of chemical fertilizers due to the decrease in fertilizers' usage by $25 \%$. In a pot experiment, it was concluded that zeolite and biochar, combined with appropriate NP fertilizer rates, can improve plant growth and provide a good source of nutrients for ryegrass establishment [29]. Other researchers, such as Kocaturk-Schumacher et al. [30], investigated the ability of zeolite enriched with digestate nutrients clinoptilolite $(\mathrm{CZ})$ to supply $\mathrm{N}$ when used as fertilizer for ryegrass, while Mehrab et al. [14] found that the $\mathrm{NH}_{4}{ }^{+}$-enriched zeolite increased $\mathrm{N}$ uptake by wheat plants, compared to the raw zeolite (control). Similarly, Paskovic et al., [31] evaluated $\mathrm{Zn}^{2+}$-containing zeolite as fertilizer and quoted that it provided favorable conditions for $\mathrm{Zn}$ uptake in calcareous soils.

Regarding vermiculite, much less information is available; however, current knowledge indicates a positive effect on crops. Indeed, in a field experiment, the combined application of vermiculite with rock phosphate or medical stone resulted in an increase in wheat (Triticum aestivum L.) yield [6]. Furthermore, vermiculite application in organic (compost) and/or inorganic $\mathrm{N}$-amended soils enhanced growth parameters, NPK uptake, and wheat yield [32]. Similarly, application of vermiculite under different organic amendments increased NPK uptake by straw and grain of barley plants [33]. Despite 
the available knowledge so far, little is known regarding the zeolite and/or vermiculite effects (including the combinational application of these materials with manure) on the growth, yields, nutrition, and physiology of vegetable crops (and especially on Solanum lycopersicon L.). According to our knowledge, only Baninasab [8] studied the effects of natural zeolite application on the growth and nutrient status of radish (Raphanus sativus L.) and Paskovic et al. [9] on radicchio mineral composition.

The hypothesis of our study was based on the premise that zeolite and vermiculite application (applied independently or in co-application with goat manure) could be used as potential, alternative, soil amendments (instead of chemical fertilizers) to sufficiently satisfy tomato crop nutritional needs. Thus, the objectives of this study were to investigate the effects of zeolite and vermiculite application (independently or in combination with goat manure) on soil fertility, tomato (Solanum lycopersicon L., cv. 'Mountain Fresh') growth, nutrition, and photosystem II (PSII) activity. The cultivar "Mountain Fresh" was chosen for the study, since it produces high quality firm and smooth fruits, with a good uniform red color.

\section{Materials and Methods}

\subsection{Plant Material, Soil Sampling and Treatments}

Tomato (S. lycopersicon L.) plants (approximately $15-20 \mathrm{~cm}$ in height, coming from a commercial nursery) were grown outdoors, in $3 \mathrm{~L}$ pots, for 112 days (from the 4th of May until the 24th of August), on soil substrate from parent material Gneiss. Pots were filled with soil collected from the region of Vasilika $\left(40^{\circ} 28^{\prime} 26.0^{\prime \prime} \mathrm{N}, 23^{\circ} 07^{\prime} 48.6^{\prime \prime} \mathrm{E}\right)$, close to the city of Thessaloniki, Macedonia, northern Greece. Most of this area is occupied with vegetable crops (especially with Solanum lycopersicon L.). Samples were collected from the upper $30 \mathrm{~cm}$ of the soil profile, since most parts of the root system of vegetable crops grow in this layer; after soil samples were received (before filling the pots), they were carefully mixed in order to achieve homogenization. The tomato plants were randomized (based on their initial height) and divided into 6 similar groups, corresponding to each one of the 6 treatments described below.

The treatments of the experiment were the following: (i) soil:ver $=80: 20$; (ii) soil:zeo $=80: 20$; (iii) soil:zeo:ver $=80: 10: 10$; (iv) control soil, i.e., no mixture of soil with amendments, only the application of controlled release fertilizer (CRF); (v) soil: GM:ver = 80:5:15; (vi) soil:GM: zeo $=80: 5: 15$. The relations of mixtures between soil and amendments were expressed in $\% w / v$. In the 4 th treatment (control soil), a total quantity of $10 \mathrm{~g}$ CRF per pot (during the whole experimental period) was applied, in two doses of $5 \mathrm{~g}$ each: the first was applied in June and the second in July. The exact composition of the applied CRF was the following: $21 \%$ total $\mathrm{N}\left(11 \% \mathrm{NH}_{4}-\mathrm{N}\right.$ and $\left.10 \% \mathrm{NO}_{3}-\mathrm{N}\right), 5 \% \mathrm{P}_{2} \mathrm{O}_{5}, 10 \% \mathrm{~K}_{2} \mathrm{O}, 3 \% \mathrm{MgO}, 6 \%$ total S, $0.02 \%$ total B, $0.3 \%$ total $\mathrm{Fe}$, and $0.02 \%$ total $\mathrm{Zn}$. The nutritional composition of GM was the following: $\mathrm{N}-2.80 \% ; \mathrm{P}-0.13 \% ; \mathrm{K}-2.54 \%$; $\mathrm{Ca}-1.15 \% ; \mathrm{Mg}-1.10 \% ; \mathrm{Na}-0.10 \% ; \mathrm{Fe}-1927 \mathrm{mg} \mathrm{kg}^{-1}$; $\mathrm{Mn}-367 \mathrm{mg} \mathrm{kg}^{-1} ; \mathrm{Zn}-81 \mathrm{mg} \mathrm{kg}^{-1}$; and $\mathrm{Cu}-15 \mathrm{mg} \mathrm{kg}^{-1}$. Thus, GM had high $\mathrm{N}$ and $\mathrm{K}$ content, while it was also a good source of $\mathrm{Fe}, \mathrm{Mn}$, and $\mathrm{Zn}$ [34]. The chemical properties of zeolite and vermiculite are presented in Table 1. As is clear from this table, $\mathrm{K}$ concentration was more than 34 times higher in zeolite than in vermiculite; similarly, $\mathrm{Ca}$ and $\mathrm{Mg}$ concentrations were more than 9 times and approximately 6.5 times higher, respectively, in zeolite, than in vermiculite (Table 1). In contrast, $\mathrm{Fe}, \mathrm{Mn}, \mathrm{Zn}$, and $\mathrm{Cu}$ concentrations were $25,1.7,1.4$, and 9.5 times higher in vermiculite than in zeolite, respectively; $\mathrm{pH}$ was also higher in vermiculite (8.83) than in zeolite (7.28) (Table 1).

Table 1. Chemical properties of zeolite and vermiculite.

\begin{tabular}{|c|c|c|c|c|c|c|c|c|c|c|c|}
\hline \multirow{2}{*}{$\begin{array}{l}\text { Kind of Soil } \\
\text { Amendment }\end{array}$} & \multirow{2}{*}{$\mathrm{pH}$} & \multirow{2}{*}{$\begin{array}{c}\text { Organic } \\
\text { Matter (\%) }\end{array}$} & $\mathrm{NO}_{3}-\mathrm{N}$ & $\mathbf{P}$ & $\mathbf{K}$ & $\mathrm{Ca}$ & $\mathrm{Mg}$ & $\mathbf{F e}$ & Mn & $\mathrm{Zn}$ & $\mathrm{Cu}$ \\
\hline & & & \multicolumn{9}{|c|}{$\mathrm{mg} \mathrm{kg}^{-1}$} \\
\hline Zeolite & 7.28 & 0.00 & 9.36 & 1.87 & 14,984 & 16,050 & 922 & 0.57 & 1.12 & 0.24 & 0.05 \\
\hline Vermiculite & 8.83 & 0.18 & 6.58 & 2.53 & 445 & 1727 & 146 & 14.44 & 1.92 & 0.33 & 0.47 \\
\hline
\end{tabular}


In each of the 6 treatments, 6 plant replicates were included; thus, the total number of experimental plants was 36. During the experiment, all the plants were irrigated daily (with an automated spray irrigation system) with high quality water, in order to achieve soil moisture of approximately $70 \%$ water holding capacity. In addition, during the whole experimental period, the plants were sprayed 5 times with $\mathrm{Cu}$ (to combat Peronospora parasitica-Phytophthora infestans) and two times with abamectin (to combat Tetranychus urticae).

\subsection{Chemical Analyses of Soil Samples and Mixtures}

The particle size of the zeolite used was $0.8-2.5 \mathrm{~mm}$ (powder size), while the swollen type of vermiculite was chosen as the second inorganic amendment. The chemical properties of zeolite and vermiculite are presented in the Table 1, while those of goat manure are quoted in paragraph 2.1. In addition, their mixtures with soil were determined according to the international protocol methods described below. After representative soil samples were received from field, they were mixed with the amendments (as described above, in the 6 treatments), and a quantity of approximately $1-1.5 \mathrm{~kg}$ from each mixture treatment (used as plant substrate) was transferred to the laboratory for chemical analyses, in order to determine the fertility of the soil mixtures. Before analyses, soil mixtures were dried at room temperature, their stones were removed, and afterwards, they were sieved to pass a 10-mesh screen. Chemical analyses included: $\mathrm{pH}$, particle size analysis, organic matter, $\mathrm{NO}_{3}-\mathrm{N}$, $\mathrm{NH}_{4}-\mathrm{N}$, available $\mathrm{P}$, exchangeable cations $(\mathrm{Ca}, \mathrm{Mg}$, and $\mathrm{K})$, and extractable micronutrients $(\mathrm{Fe}, \mathrm{Mn}, \mathrm{Zn}$, and $\mathrm{Cu}$ ). The above mentioned parameters were determined as follows: $\mathrm{pH}$ in a soil-distilled water paste (1:1) [35], particle size analysis according to the Bouyoucos method [36], and organic matter with potassium dichromate $\left(\mathrm{K}_{2} \mathrm{Cr}_{2} \mathrm{O}_{7}\right)$ [37], while $\mathrm{NO}_{3}{ }^{-}-\mathrm{N}$ concentration was determined according the $\mathrm{VCl}_{3} / \mathrm{Griess}$ method [38] and the extractable $\mathrm{NH}_{4}{ }^{+}-\mathrm{N}$ was measured after extracting $2.5 \mathrm{~g}$ of soil with $15 \mathrm{~mL}$ of $2 \mathrm{M} \mathrm{KCl}$, for $1 \mathrm{~h} \mathrm{[39].} \mathrm{The} \mathrm{available} \mathrm{P}$ was carried out according to the Olsen method [40] and the exchangeable cations according to the method of ammonium acetate $\left(\mathrm{CH}_{3} \mathrm{COONH}_{4}\right)$ [41], while the extractable micronutrients $(\mathrm{Fe}, \mathrm{Mn}, \mathrm{Zn}$, and $\mathrm{Cu}$ ) were determined after extraction of $10 \mathrm{~g}$ soil with DTPA solution, $\mathrm{pH} 7.3$ [42]. The concentrations of $\mathrm{Ca}, \mathrm{Mg}, \mathrm{K}, \mathrm{Fe}, \mathrm{Mn}, \mathrm{Zn}$, and $\mathrm{Cu}$ were determined by the ICP (Perkin Elmer-Optical Emission Spectrometer, OPTIMA 2100 DV) method [43].

\subsection{Plant Growth Data}

At the end of the experiment, the main shoot length for all the experimental plants was measured. Then, the leaves were separated from the shoots and the roots from the other plant parts. Before being washed, the fresh weights ( $\mathrm{fw}$ ) of roots, stems, and leaves were determined. By adding the $\mathrm{fw}$ of all the plant parts, the total plant fw was calculated. After all the plant tissues were carefully washed (once with tap and twice with distilled water), they were dried at $75^{\circ} \mathrm{C}$ for $48 \mathrm{~h}$. Then, the dry weights (dw) of roots, stems, and leaves were determined. By adding the $\mathrm{dw}$ of all the plant parts, the total plant $\mathrm{dw}$ was calculated. In addition, the ratio (leaf + stem)/root $\mathrm{dw}$ was calculated.

\subsection{Tissue Nutrient Analyses and Total Plant Nutrient Content}

At the end of the 112-day experimental period, after the plants were harvested and the tissues were separated, washed, and dried (at $75^{\circ} \mathrm{C}$ for $24 \mathrm{~h}$ ), they were ground to a fine powder, in order to pass a 30 -mesh screen. A portion of $0.5 \mathrm{~g}$ of fine powder of each sample was dry-ashed in a muffle furnace, at $515^{\circ} \mathrm{C}$ for $5 \mathrm{~h}$. Then, the ash was dissolved with $3 \mathrm{~mL}$ of $6 \mathrm{~N} \mathrm{HCl}$ and diluted with double distilled water up to $50 \mathrm{~mL}$. The concentrations of $\mathrm{P}, \mathrm{K}, \mathrm{Ca}, \mathrm{Mg}, \mathrm{Fe}, \mathrm{Mn}, \mathrm{Zn}$, and $\mathrm{Cu}$ were determined by ICP (Perkin Elmer-Optical Emission Spectrometer, OPTIMA 2100 DV, Markham, ON, Canada) [43]. Nitrogen was determined by the Kjeldahl method [44]. Macronutrient concentrations were expressed in $\% \mathrm{dw}$, while those of the micronutrients were expressed in $\mathrm{mg} \mathrm{kg}^{-1}$. Multiplying the concentration of each nutrient ( $\mu \mathrm{g}$ or $\mathrm{mg} \mathrm{g}^{-1} \mathrm{dry}$ weight) found in each plant part by the corresponding $\mathrm{dw}$, the content (absolute quantity) of each nutrient in each plant part, at the end of the experiment, was calculated. By addition of the nutrient contents of different plant parts, the total nutrient content ( $\mu \mathrm{g}$ or $\mathrm{mg}$ ) per plant 
and the total nutrient uptake per plant were computed. With regard to the determination of nutrient concentrations in tomatoes, the fruits were crushed and dried at $75{ }^{\circ} \mathrm{C}$ for $24 \mathrm{~h}$ and dry-ashed at $515{ }^{\circ} \mathrm{C}$ for $5 \mathrm{~h}$, and the determination of nutrients was realized according to the methodology described above.

\subsection{Chlorophyll Fluorescence Measurements}

At the end of the experiment, the following chlorophyll fluorescence parameters were determined: $\mathrm{F}_{\mathrm{v}} / \mathrm{F}_{\mathrm{m}}$-maximum quantum yield of primary photochemistry; $\mathrm{F}_{0}$-minimum fluorescence; $\mathrm{F}_{\mathrm{m}}$-maximum fluorescence; $\mathrm{F}_{\mathrm{v}}=\mathrm{F}_{\mathrm{m}}-\mathrm{F}_{0}$-variable fluorescence; performance index (PI) reflects the functionality of both photosystems I and II and provides quantitative information on the current state of plant performance under stress conditions [45]. All these parameters were determined in young mature leaves (from the upper part of the main shoot) of Solanum lycopersicon L. plants by the PAM-2000 fluorometer (Heinz Walz GmbH, Effeltrich, Germany), after preconditioning of the leaves in the dark for $20 \mathrm{~min}$ [46].

\subsection{Statistical Analysis}

The experimental design consisted of a $6 \times 1$ completely randomized factorial, with 6 fertilization treatments (application of inorganic and organic soil amendments) and one Solanum lycopersicon $\mathrm{L}$. cultivar ("Mountain Fresh"). In each of the 6 treatments, 6 replicates were included (thus, the total number of experimental plants was $6 \times 6=36$ ). The data were statistically analyzed by the SPSS statistical program (one-way ANOVA) and for the comparison of the mean values among the treatments, Duncan's multiple range test, for $p \leq 0.05$, was used.

\section{Results}

\subsection{Chemical Properties of the Amendments and Soil Fertility among the Treatments}

After manure application, organic matter increased from $1.14 \%$ in the control soil to $2.72 \%$ and $1.93 \%$ in the manure + ver and manure + zeo treatments, respectively (Table 2). In addition, $\mathrm{NO}_{3}-\mathrm{N}$ and P concentrations were up to 45 times and 19 times higher, respectively, in the manure + ver and manure + zeo treatments, compared to the four other ones. Exchangeable $\mathrm{K}$ increased by approximately 25 times, 16.5 times, and 37.5 times in the zeo, zeo + ver, and manure + zeo treatments (compared to the control soil), respectively (Table 2), after the application of the amendments. DTPA-extractable Fe and Mn concentrations were decreased after zeolite, vermiculite, and manure application (Table 3), while extractable $\mathrm{Zn}$ was increased by approximately: (i) 3 times after zeolite and vermiculite application and (ii) 5-6 times after combined zeolite/vermiculite and manure application, compared to the control soil (Table 3).

Table 2. Soil fertility parameters among the 6 treatments.

\begin{tabular}{|c|c|c|c|c|c|c|c|c|c|c|}
\hline \multirow{2}{*}{$\begin{array}{l}\text { Treatment (Soil } \\
\text { Amend.) }\end{array}$} & \multirow{2}{*}{$\begin{array}{l}\text { Soil } \\
\text { Text. }\end{array}$} & \multirow{2}{*}{$\mathrm{pH}$} & Org. C & Org. Matter & $\mathrm{NO}_{3}-\mathrm{N}$ & $\mathrm{NH}_{4}-\mathrm{N}$ & $\mathbf{P}$ & $\mathbf{K}$ & $\mathrm{Ca}$ & Mg \\
\hline & & & \multicolumn{2}{|r|}{$\%$} & \multicolumn{6}{|c|}{$\mathrm{mg} \mathrm{kg}^{-1}$} \\
\hline Vermiculite (Ver) & SL & 6.85 & 0.81 & 1.40 & 5.37 & 14.46 & 3.58 & 105 & 2016 & 376 \\
\hline Zeolite (Zeo) & SL & 6.47 & 0.71 & 1.22 & 2.95 & 13.79 & 2.88 & 1613 & 2550 & 339 \\
\hline Zeo + Ver & SL & 6.95 & 0.89 & 1.54 & 3.74 & 14.12 & 2.53 & 1062 & 2481 & 360 \\
\hline Control soil & SL & 6.52 & 0.66 & 1.14 & 2.16 & 15.36 & 1.44 & 65 & 1711 & 392 \\
\hline Manure + Ver & SL & 6.54 & 1.58 & 2.72 & 97.31 & 15.71 & 23.67 & 262 & 2146 & 446 \\
\hline Manure + Zeo & SL & 6.68 & 1.11 & 1.93 & 56.58 & 31.63 & 27.08 & 2433 & 2964 & 381 \\
\hline
\end{tabular}


Table 3. Soil micronutrient concentrations among the 6 treatments.

\begin{tabular}{cccccc}
\hline $\begin{array}{c}\text { Treatment (Soil } \\
\text { Amend.) }\end{array}$ & Fe & Mn & Zn & Cu & B \\
\cline { 2 - 6 } & & \multicolumn{5}{c}{$\mathbf{m g ~ k g}^{-\mathbf{1}}$} \\
\hline Vermiculite (Ver) & 21.33 & 20.45 & 0.79 & 1.66 & 0.35 \\
Zeolite (Zeo) & 18.31 & 18.32 & 0.70 & 1.31 & 0.39 \\
Zeo + Ver & 23.02 & 22.33 & 0.70 & 1.70 & 0.29 \\
Control soil & 27.49 & 36.32 & 0.26 & 2.81 & 0.33 \\
Manure + Ver & 18.47 & 21.26 & 1.48 & 1.94 & 0.80 \\
Manure + Zeo & 16.52 & 22.21 & 1.13 & 1.96 & 0.49 \\
\hline
\end{tabular}

\subsection{Plant Growth}

The highest total plant biomass was found in the CRF treatment (control), while significantly lower biomass was determined in the ver, manure + ver, and manure + zeo treatments (Table 4). Zeolite application promoted the ratio (leaf + stem) $\mathrm{dw} / \operatorname{root} \mathrm{dw}$, since its highest values were found in the zeo (10.31), manure + zeo (10.02), and zeo + ver (9.90) treatments. In contrast, the lowest value of the ratio $($ leaf + stem) $d w /$ root $d w$ was determined in the manure + ver treatment (6.24) (Table 4).

Table 4. Plant growth parameters for Solanum lycopersicon L. plants among the six treatments.

\begin{tabular}{|c|c|c|c|c|c|c|c|c|c|}
\hline $\begin{array}{l}\text { Treatment (Soil } \\
\text { Amendment) }\end{array}$ & \multicolumn{2}{|c|}{ Leaf Weight (g) } & \multicolumn{2}{|c|}{ Stem Weight (g) } & \multicolumn{2}{|c|}{ Root Weight (g) } & $\begin{array}{c}\text { Leaf }+ \\
\text { Stem/Root (dw) }\end{array}$ & \multicolumn{2}{|c|}{ Total Biomass (g) } \\
\hline Vermiculite (Ver) & $27.43^{b c}$ & $3.76 c$ & $109.09 a$ & $13.30 \mathrm{a}$ & $11.01 \mathrm{a}$ & $1.65 b$ & $8.95 \mathrm{ab}$ & $124.70 \mathrm{ab}$ & $16.71 b$ \\
\hline Zeo + Ver & $39.25^{a}$ & $4.69 \mathrm{~b}$ & $109.94 a$ & $15.02 \mathrm{a}$ & $13.14 \mathrm{a}$ & $1.93 b$ & $9.90 \mathrm{a}$ & $162.63 a$ & $21.49 \mathrm{ab}$ \\
\hline Control (CRF) & $43.41^{\mathrm{a}}$ & $6.67 \mathrm{a}$ & $119.17 \mathrm{a}$ & $16.08 \mathrm{a}$ & $17.03 a$ & $3.37 \mathrm{a}$ & $8.21 \mathrm{ab}$ & $179.61 \mathrm{a}$ & $28.78 \mathrm{a}$ \\
\hline
\end{tabular}

Numbers are means of six replicates $(\mathrm{N}=6)$. The different letters $\left({ }^{a}, \mathrm{ab}, \mathrm{b}, \mathrm{bc}, \mathrm{c}\right)$, in the same column, symbolize statistically significant differences among the six treatments, according to Duncan's multiple range test, for $p \leq 0.05$.

\subsection{Tissue Nutrient Concentrations and Total Plant Nutrient Content}

Significantly higher foliar $\mathrm{N}$ was found in the CRF $(4.83 \% \mathrm{dw})$ and zeo + ver $(4.24 \% \mathrm{dw})$ treatments, compared to the manure + ver $(3.42 \% \mathrm{dw})$ (Table 5$)$. In contrast, significantly higher leaf $\mathrm{P}$ was determined in the manure + ver treatment $(1.48 \% \mathrm{dw})$, compared to the four other ones (ver, zeo, zeo + ver, manure + zeo), while an insignificant difference in foliar P was found between the manure + ver and the CRF treatments (Table 5). With regard to K nutrition, significantly higher foliar K concentration was found in the zeo treatment $(5.93 \% \mathrm{dw})$, compared to those determined in the non-zeo treatments (ver, CRF, manure + ver); insignificant differences in leaf K were found between: (i) the zeo, (ii) the zeo + ver, and (iii) the manure + zeo treatments (Table 5). Leaf Ca in the CRF was significantly lower $(2.66 \% \mathrm{dw})$ compared to the concentrations determined in the ver and zeo treatments (3.40 and $3.86 \% \mathrm{dw}$, respectively) (Table 5). 
Table 5. Foliar nutrient concentrations for Solanum lycopersicon L. plants among the six treatments.

\begin{tabular}{ccccccccccc}
\hline \multirow{2}{*}{$\begin{array}{c}\text { Treatment (Soil } \\
\text { Amendment) }\end{array}$} & $\mathbf{N}$ & $\mathbf{P}$ & $\mathbf{K}$ & $\mathbf{C a}$ & $\mathbf{M g}$ & $\mathbf{B}$ & $\mathbf{F e}$ & $\mathbf{M n}$ & $\mathbf{Z n}$ & $\mathbf{C u}$ \\
\cline { 2 - 10 } & \multicolumn{9}{c}{$\mathbf{~} \mathbf{d w}$} \\
\hline Vermiculite (Ver) & $3.97^{\mathrm{ab}}$ & $0.93^{\mathrm{b}}$ & $4.11^{\mathrm{c}}$ & $3.40^{\mathrm{a}}$ & $0.77^{\mathrm{a}}$ & $93^{\mathrm{a}}$ & $96^{\mathrm{ab}}$ & $138^{\mathrm{ab}}$ & $32^{\mathrm{a}}$ & $855^{\mathrm{a}}$ \\
Zeolite (Zeo) & $3.60^{\mathrm{ab}}$ & $0.90^{\mathrm{b}}$ & $5.93^{\mathrm{a}}$ & $3.86^{\mathrm{a}}$ & $0.73^{\mathrm{a}}$ & $76^{\mathrm{ab}}$ & $107^{\mathrm{a}}$ & $89^{\mathrm{bc}}$ & $31^{\mathrm{a}}$ & $546^{\mathrm{b}}$ \\
Zeo + Ver & $4.24^{\mathrm{a}}$ & $0.91^{\mathrm{b}}$ & $5.13^{\mathrm{ab}}$ & $2.99^{\mathrm{ab}}$ & $0.75^{\mathrm{a}}$ & $79^{\mathrm{ab}}$ & $100^{\mathrm{ab}}$ & $92^{\mathrm{b}}$ & $24^{\mathrm{ab}}$ & $189^{\mathrm{c}}$ \\
Control (CRF) & $4.83^{\mathrm{a}}$ & $1.16^{\mathrm{ab}}$ & $4.27^{\mathrm{bc}}$ & $2.66^{\mathrm{b}}$ & $0.85^{\mathrm{a}}$ & $80^{\mathrm{ab}}$ & $111^{\mathrm{a}}$ & $194^{\mathrm{a}}$ & $26^{\mathrm{ab}}$ & $192^{\mathrm{c}}$ \\
Manure + Ver & $3.42^{\mathrm{b}}$ & $1.48^{\mathrm{a}}$ & $4.37^{\mathrm{bc}}$ & $3.02^{\mathrm{ab}}$ & $0.81^{\mathrm{a}}$ & $80^{\mathrm{ab}}$ & $81^{\mathrm{b}}$ & $97^{\mathrm{b}}$ & $21^{\mathrm{b}}$ & $106^{\mathrm{d}}$ \\
Manure + Zeo & $4.05^{\mathrm{ab}}$ & $0.89^{\mathrm{b}}$ & $4.83^{\mathrm{ab}}$ & $3.15^{\mathrm{ab}}$ & $0.72^{\mathrm{a}}$ & $62^{\mathrm{b}}$ & $95^{\mathrm{ab}}$ & $75^{\mathrm{c}}$ & $21^{\mathrm{b}}$ & $69^{\mathrm{e}}$ \\
\hline
\end{tabular}

Numbers are means of six replicates $(\mathrm{N}=6)$. The different letters, in the same column, symbolize statistically significant differences among the six treatments, according to Duncan's multiple range test, for $p \leq 0.05$.

With regard to micronutrient nutrition, a significant difference in leaf B was found only between the ver and manure + zeo treatments (Table 5). Significantly higher foliar Fe was found in the zeo and CRF treatments (107 and $111 \mathrm{mg} \mathrm{kg}^{-1}$, respectively), compared to the manure + ver $\left(81 \mathrm{mg} \mathrm{kg}^{-1}\right)$ (Table 5); leaf Mn was significantly higher in the CRF treatment $\left(194 \mathrm{mg} \mathrm{kg}^{-1}\right)$, compared to the concentrations determined in the zeo + ver, manure + ver, manure + zeo, and zeo treatments (Table 5). Leaf $\mathrm{Zn}$ was significantly higher in the ver and zeo treatments (32 and $31 \mathrm{mg} \mathrm{kg}^{-1}$, respectively), compared to those found in the manure + ver and manure + zeo $\left(21 \mathrm{mg} \mathrm{kg}^{-1}\right)$ (Table 5). Finally, foliar $\mathrm{Cu}$ was widely varied among the treatments: the highest foliar $\mathrm{Cu}$ concentration was determined in the ver treatment $\left(855 \mathrm{mg} \mathrm{kg}^{-1}\right)$, followed by the corresponding concentrations in the zeo $\left(546 \mathrm{mg} \mathrm{kg}^{-1}\right)$, CRF $\left(192 \mathrm{mg} \mathrm{kg}^{-1}\right)$, zeo $+\operatorname{ver}\left(189 \mathrm{mg} \mathrm{kg}^{-1}\right)$, manure $+\operatorname{ver}\left(106 \mathrm{mg} \mathrm{kg}^{-1}\right)$, and manure + zeo $\left(69 \mathrm{mg} \mathrm{kg}^{-1}\right)$ treatments (Table 5).

Significant differences in stem and root concentrations were found for most nutrients among the treatments (data not shown). With regard to total nutrient content per plant, significantly higher $\mathrm{N}$ content was recorded in the CRF ( $>700 \mathrm{mg}$ ), followed by the corresponding values in the zeo (approximately $400 \mathrm{mg}$ ) and zeo + ver (approximately $300 \mathrm{mg}$ ) treatments; the lowest $\mathrm{N}$ contents were determined in the manure + zeo (approximately $200 \mathrm{mg}$ ) and manure + ver $(<100 \mathrm{mg}$ ) (Figure 1A). Significantly higher P content was found in the CRF (approximately $230 \mathrm{mg}$ ), followed by the content in the manure + zeo treatment (slightly below $200 \mathrm{mg}$ ); the lowest $\mathrm{P}$ contents were determined in the ver (approximately $80 \mathrm{mg}$ ) and zeo + ver treatments (slightly below $100 \mathrm{mg}$ ) (Figure 1B). Potassium content was significantly higher in the CRF, zeo, and manure + zeo treatments (approximately 850-1000 mg), compared to the ver (approximately $450 \mathrm{mg}$ ) and manure + ver (approximately $600 \mathrm{mg}$ ) (Figure 1C). 


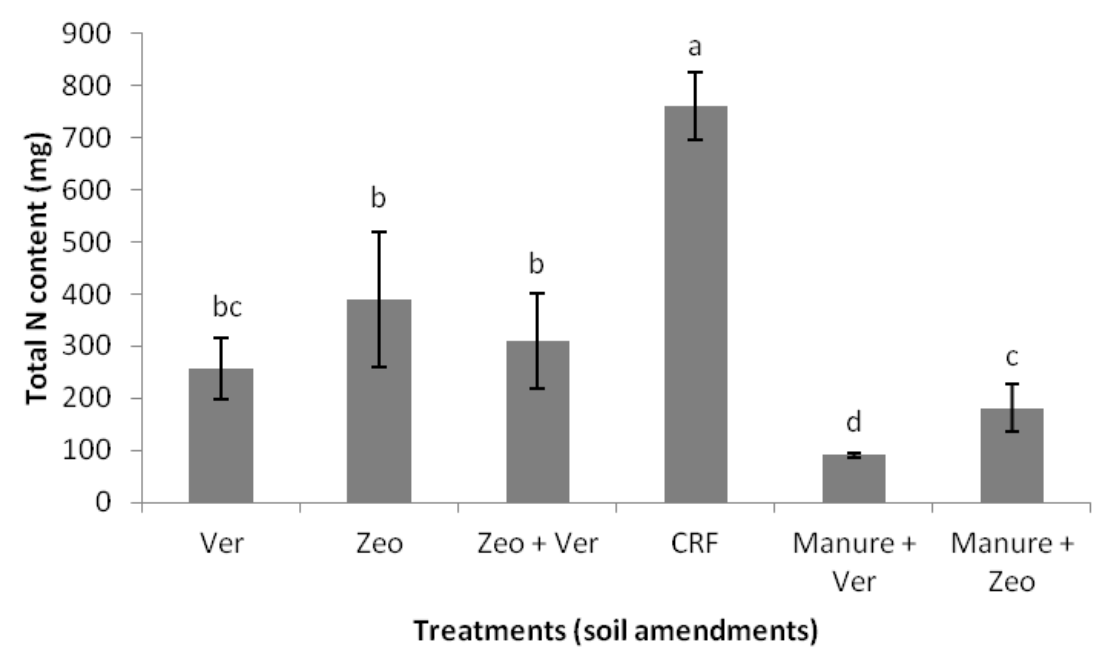

(A)

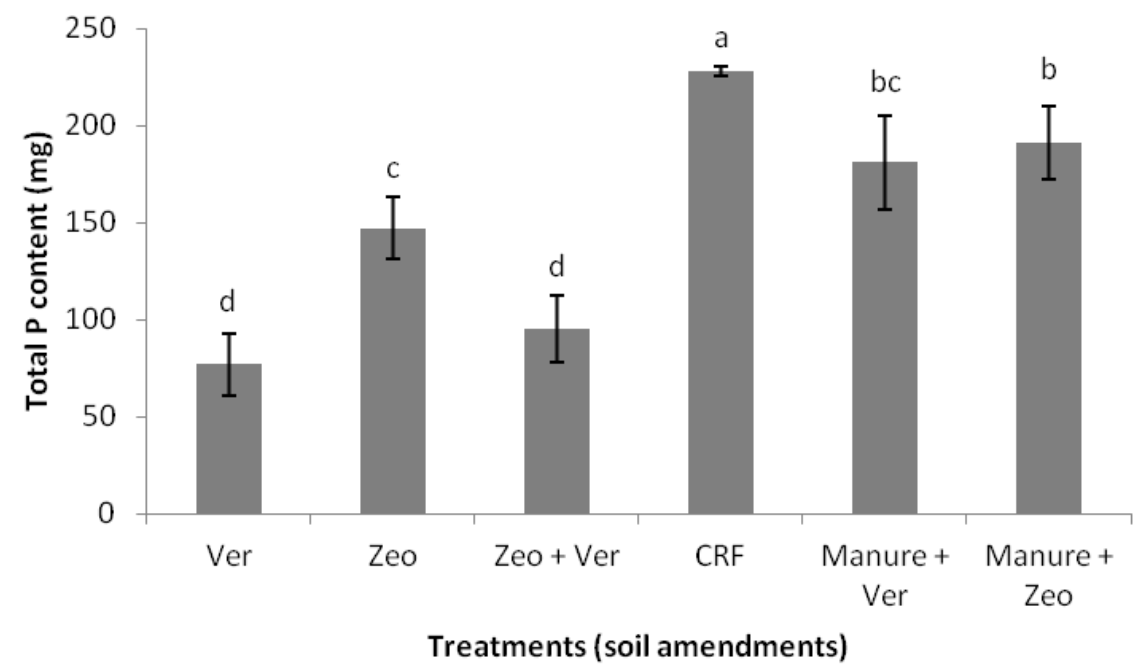

(B)

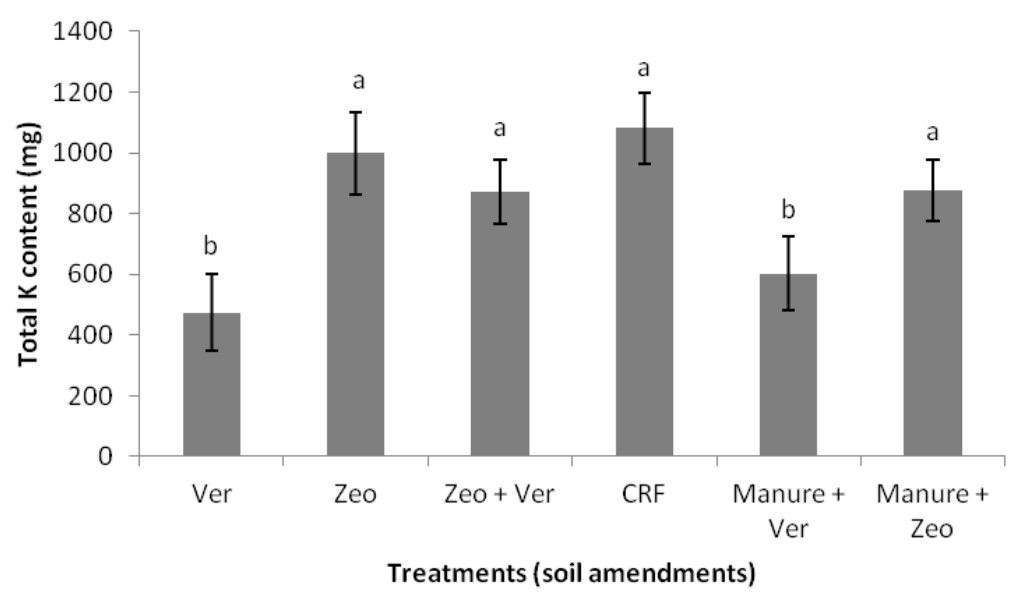

(C)

Figure 1. Cont. 


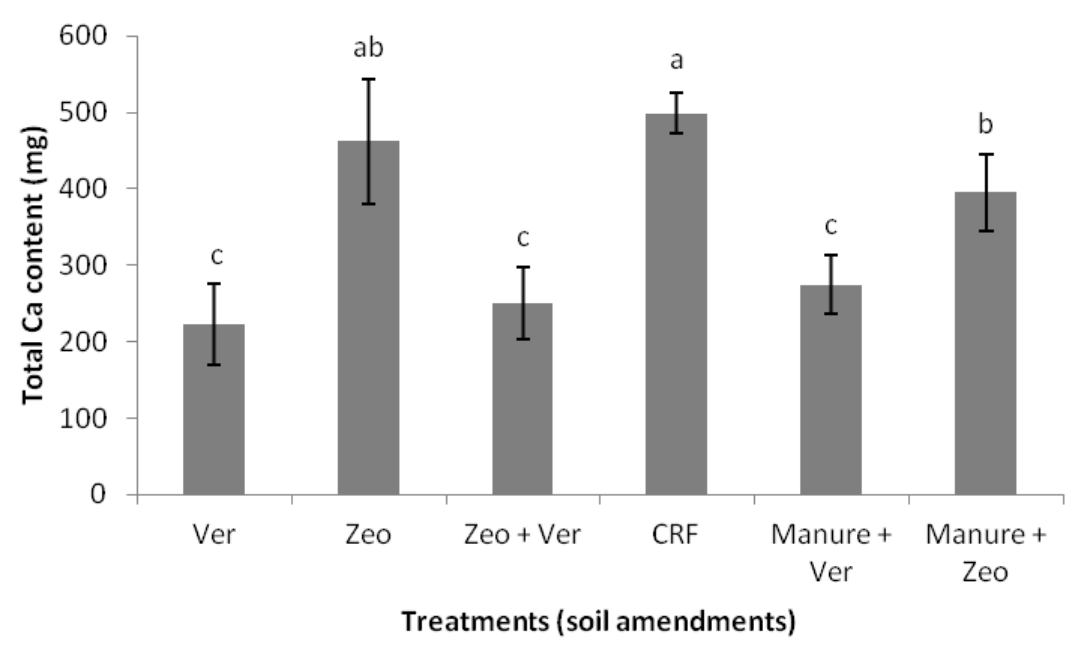

(D)

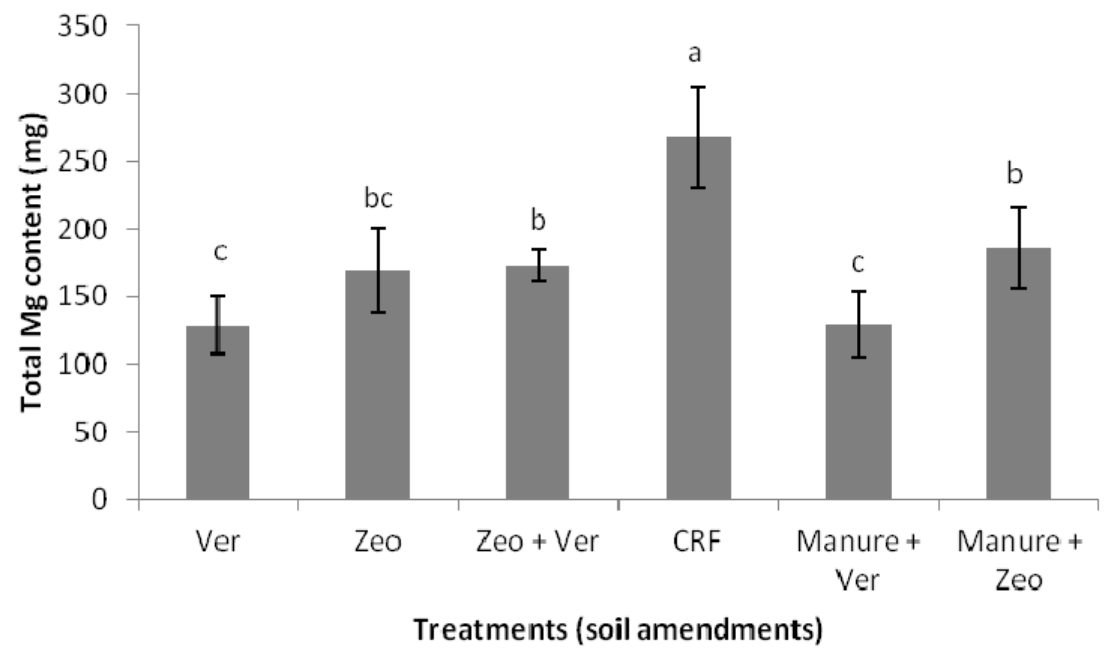

(E)

Figure 1. Total plant $\mathrm{N}(\mathbf{A}), \mathrm{P}(\mathbf{B}), \mathrm{K}(\mathbf{C}), \mathrm{Ca}(\mathbf{D})$, and $\mathrm{Mg}(\mathbf{E})$ content (mg) among the six treatments.

The highest Ca content was recorded in the CRF (approximately $500 \mathrm{mg}$ ), while significantly lower contents were found in the manure + zeo (approximately $400 \mathrm{mg}$ ), manure + ver (approximately $280 \mathrm{mg}$ ), zeo + ver (approximately $250 \mathrm{mg}$ ), and ver (slightly above $200 \mathrm{mg}$ ) treatments (Figure 1D). With regard to $\mathrm{Mg}$, significantly higher Mg content was determined in the CRF (approximately 270 $\mathrm{mg}$ ), compared to the other five treatments (it varied from approximately 130 to $180 \mathrm{mg}$ ) (Figure 1E). A similar tendency was also found for $\mathrm{Fe}$ and $\mathrm{Zn}$, where significantly higher contents were determined in the CRF (approximately $5000 \mu \mathrm{g}$ for Fe and $1700 \mu \mathrm{g}$ for $\mathrm{Zn}$ ), compared to the other treatments (Figure 2A,C). Insignificant differences between the CRF and zeo treatments were found for $\mathrm{Mn}$ and $\mathrm{Cu}$ contents; however, significantly higher $\mathrm{Mn}$ and $\mathrm{Cu}$ contents were determined in these two treatments, compared to the four other ones (Figure 2B,D). 


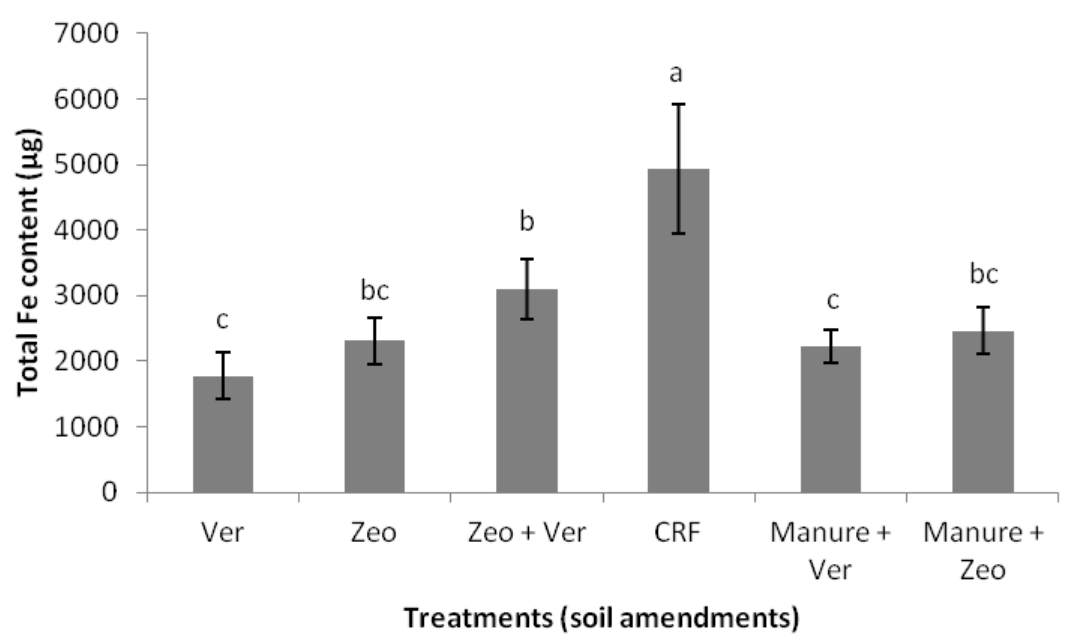

(A)

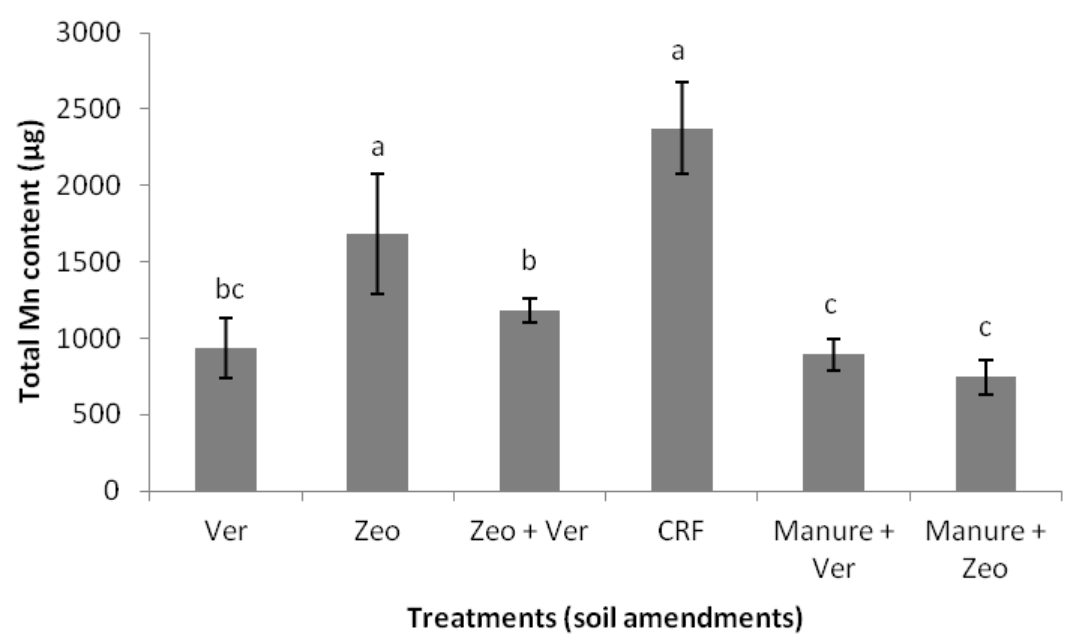

(B)

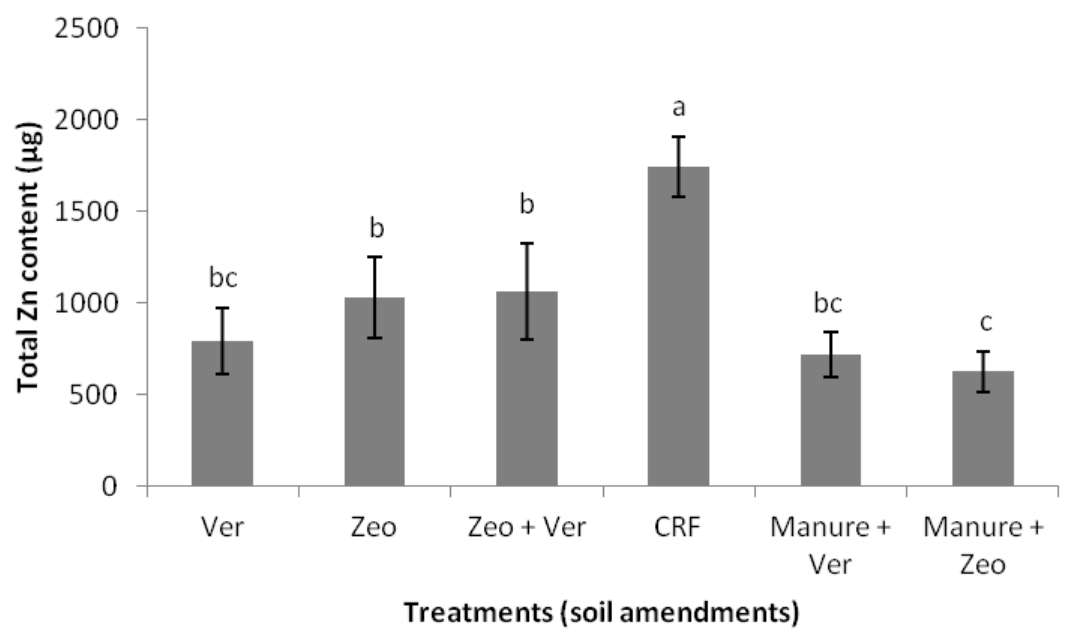

(C)

Figure 2. Cont. 


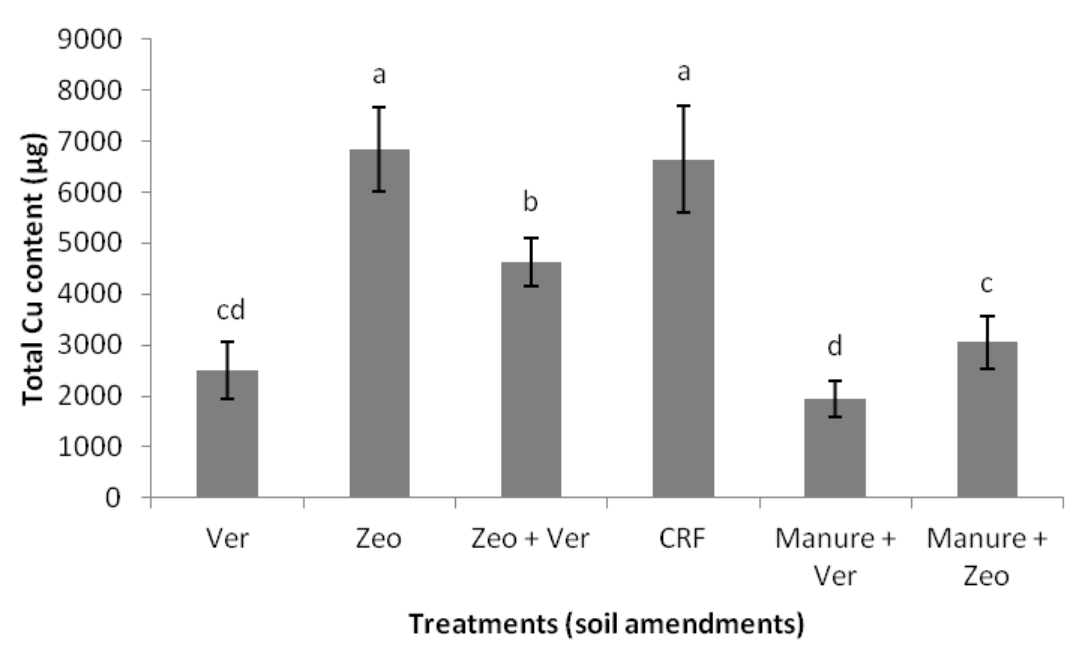

(D)

Figure 2. Total plant $\mathrm{Fe}(\mathbf{A}), \mathrm{Mn}(\mathbf{B}), \mathrm{Zn}(\mathbf{C})$, and $\mathrm{Cu}(\mathbf{D})$ content $(\mu \mathrm{g})$ among the six treatments.

\subsection{Fruit Weight and Nutrient Concentrations}

The highest mean fruit weight was recorded in the CRF; significantly lower fruit weights were found in the other five treatments, compared to the CRF. The lowest mean fruit weight was determined in the manure + ver, followed by that in the ver treatment (Figure 3). It is quite remarkable that the lowest fruit $\mathrm{Zn}$ concentration was recorded in the manure + ver treatment $\left(15 \mathrm{mg} \mathrm{kg}^{-1}\right)$, followed by that in the ver $\left(19 \mathrm{mg} \mathrm{kg}^{-1}\right)$ (Table 6). In the same (ver) treatment, the lowest fruit $\mathrm{K}$ concentration was found $(2.89 \% \mathrm{dw})$; in contrast, the highest $\mathrm{K}$ concentration was determined in the manure + zeo $(5.30 \% \mathrm{dw})$, followed by the concentration in zeo $(4.75 \% \mathrm{dw})$ (Table 6$)$.

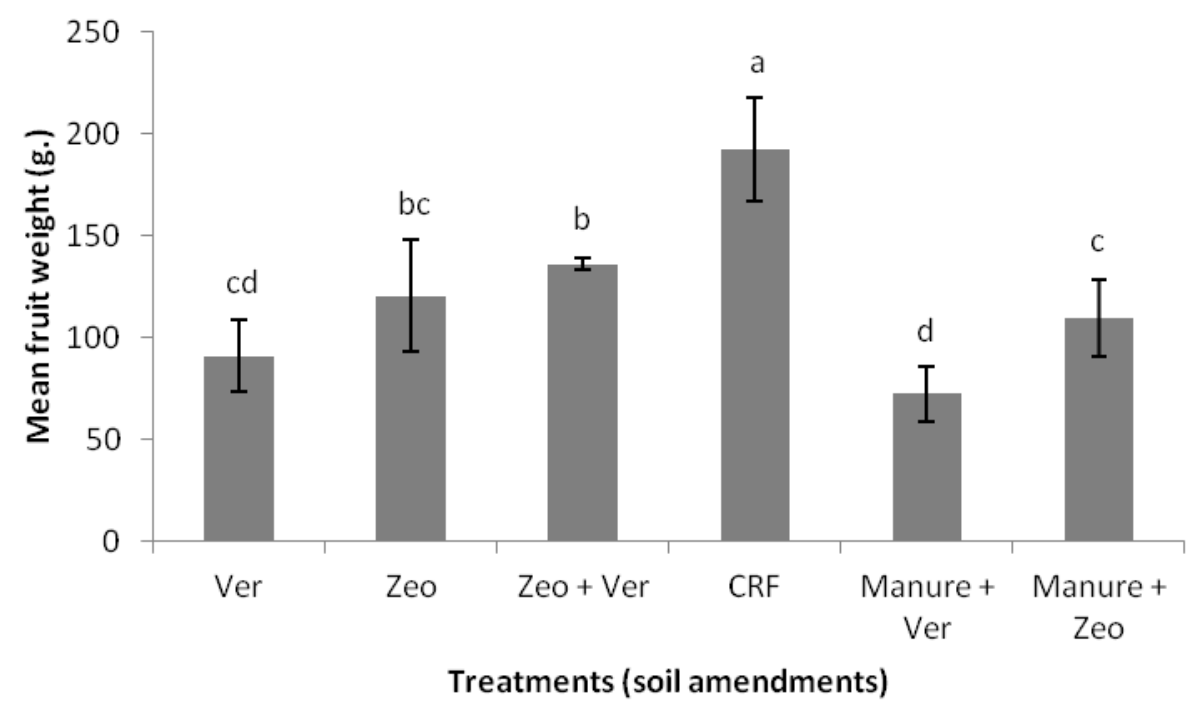

Figure 3. Mean fruit weight (g) among the six treatments. 
Table 6. Fruit nutrient concentrations for Solanum lycopersicon L. plants among the six treatments.

\begin{tabular}{|c|c|c|c|c|c|c|c|c|c|c|}
\hline \multirow{2}{*}{$\begin{array}{l}\text { Treatment (Soil } \\
\text { Amendment) }\end{array}$} & $\mathbf{N}$ & $\mathbf{P}$ & $\mathbf{K}$ & $\mathrm{Ca}$ & Mg & B & $\mathrm{Fe}$ & Mn & $\mathrm{Zn}$ & $\mathrm{Cu}$ \\
\hline & \multicolumn{5}{|c|}{$\% d w$} & \multicolumn{5}{|c|}{$\mathrm{mg} \mathrm{kg}^{-1}$} \\
\hline Vermiculite (Ver) & $2.95^{b}$ & $0.75^{b c}$ & $2.89^{\mathrm{C}}$ & $0.17 \mathrm{ab}$ & $0.18^{a b}$ & $20^{b}$ & $55^{\mathrm{ab}}$ & $15^{\mathrm{a}}$ & $19^{\mathrm{ab}}$ & $17^{\mathrm{ab}}$ \\
\hline Zeolite (Zeo) & $3.24^{\mathrm{ab}}$ & $0.97 \mathrm{ab}$ & $4.75^{\mathrm{a}}$ & $0.21^{\mathrm{a}}$ & $0.22^{a}$ & $20^{b}$ & $71^{\mathrm{a}}$ & $18^{\mathrm{a}}$ & $25^{\mathrm{a}}$ & $22^{\mathrm{a}}$ \\
\hline Zeo + Ver & $3.06^{b}$ & $0.49^{c}$ & $4.11^{\mathrm{b}}$ & $0.13^{b}$ & $0.13^{b}$ & $21^{\mathrm{ab}}$ & $55^{\mathrm{ab}}$ & $15^{\mathrm{a}}$ & $24^{\mathrm{a}}$ & $4^{\mathrm{d}}$ \\
\hline Control (CRF) & $4.25^{\mathrm{a}}$ & $0.93^{b}$ & $3.69^{b}$ & $0.15^{\mathrm{ab}}$ & $0.17^{\mathrm{ab}}$ & $23^{\mathrm{ab}}$ & $65^{\mathrm{ab}}$ & $17^{\mathrm{a}}$ & $20^{\mathrm{ab}}$ & $18^{\mathrm{ab}}$ \\
\hline Manure + Ver & $2.56^{\mathrm{b}}$ & $1.50^{\mathrm{a}}$ & $4.22^{a b}$ & $0.23^{a}$ & $0.23^{a}$ & $30^{\mathrm{a}}$ & $47^{b}$ & $22^{a}$ & $15^{\mathrm{b}}$ & $13^{b}$ \\
\hline Manure + Zeo & $2.96^{\mathrm{b}}$ & $1.06^{\mathrm{ab}}$ & $5.30^{\mathrm{a}}$ & $0.15^{\mathrm{ab}}$ & $0.16^{\mathrm{ab}}$ & $19^{b}$ & $49^{b}$ & $14^{\mathrm{a}}$ & $24^{\mathrm{a}}$ & $7^{c}$ \\
\hline
\end{tabular}

Numbers are means of six replicates $(\mathrm{N}=6)$. The different letters, in the same column, symbolize statistically significant differences among the six treatments, according to Duncan's multiple range test, for $p \leq 0.05$.

\subsection{Chlorophyll Fluorescence Parameters $\left(F_{v} / F_{m}, F_{v} / F_{0}\right.$, and Performance Index-PI)}

The highest values for the chlorophyll fluorescence parameters were recorded in the ver treatment, followed by those determined in the zeo + ver and CRF treatments; the lowest values were found in the zeo and manure + ver treatments (Figure $4 \mathrm{~A}-\mathrm{C}$ ).

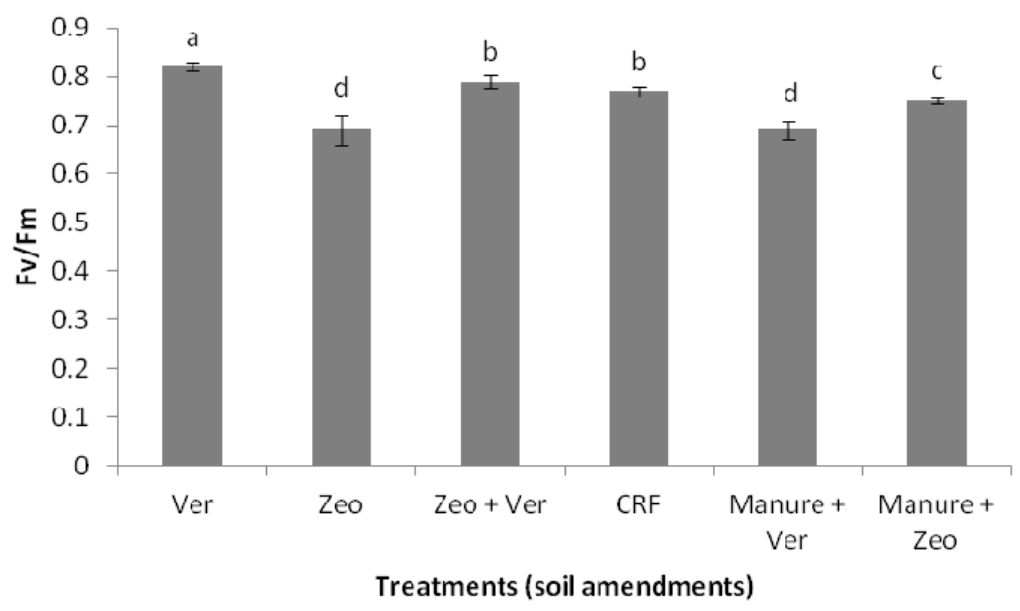

(A)

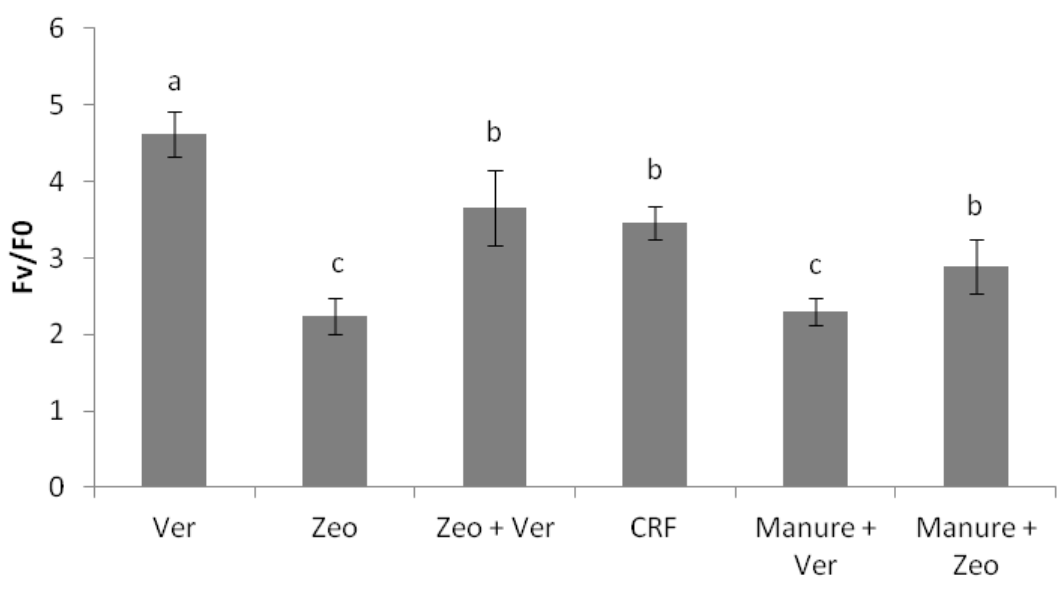

Treatments (soil amendments)

(B)

Figure 4. Cont. 


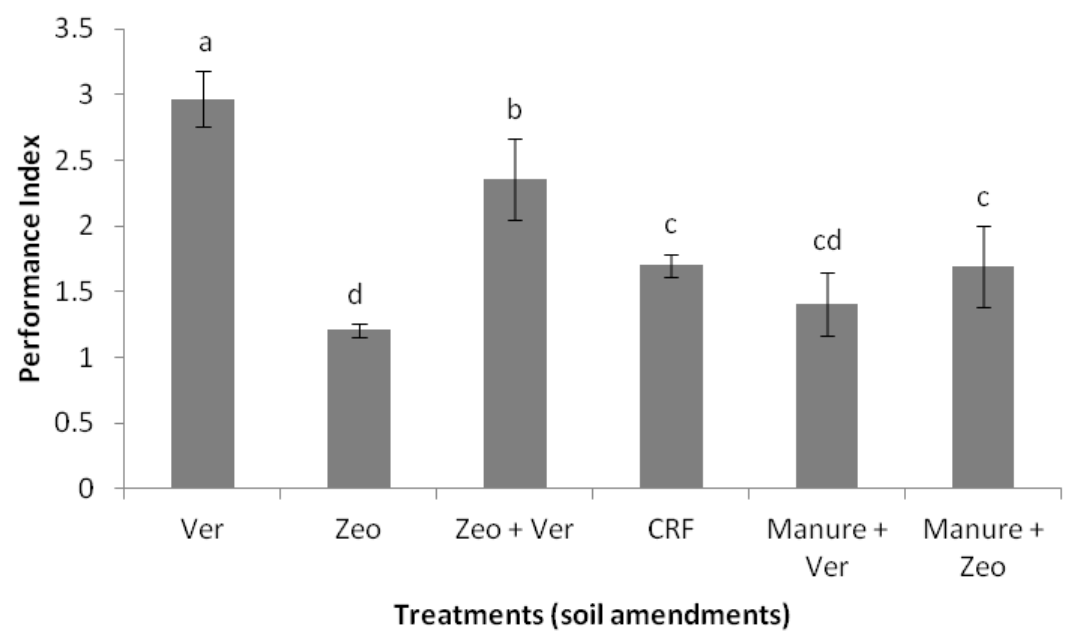

(C)

Figure 4. Photosystem II activity, as expressed by the chlorophyll fluorescence parameters $\mathrm{F}_{\mathrm{v}} / \mathrm{F}_{\mathrm{m}}(\mathbf{A})$, $\mathrm{F}_{\mathrm{v}} / \mathrm{F}_{0}(\mathbf{B})$, and Performance Index-PI (C), among the six treatments.

\section{Discussion}

Potassium, $\mathrm{Ca}$, and $\mathrm{Mg}$ contents were significantly higher in zeolite than in vermiculite (Table 1); the significantly higher $\mathrm{K}$ content in zeolite led to the significantly higher soil exchangeable $\mathrm{K}$ (more than 15 times higher, compared to vermiculite) and to an impressive boosting in soil $\mathrm{K}$, compared to the control (Table 2). The beneficial effects of zeolite application as soil amendments (especially on the increase in exchangeable $\mathrm{K}$ and afterwards on the increase in $\mathrm{Ca}$ ) have also been referred to by other researchers $[47,48]$. Apart from the increase in exchangeable $\mathrm{K}$, zeolite application significantly increased foliar $\mathrm{K}$; indeed, the highest leaf $\mathrm{K}$ concentration was found in zeolite $(5.93 \% \mathrm{dw})$, followed by the concentrations in zeo + ver and manure + zeo treatments ( 5.13 and $4.83 \% \mathrm{dw}$, respectively) (Table 5). Our results for the significant increase in $\mathrm{K}$ uptake after zeolite addition are in agreement to those of Assimakopoulou et al. [19] for pepper plants and to those of Doostikhah et al. [5] for tomato plants. Optimum foliar $\mathrm{K}$ levels in tomato plants should be within the range from 3.0 to $6.0 \%$ $\mathrm{dw}$ [49]; therefore, in all the treatments of our experiment, leaf $\mathrm{K}$ concentrations were within the range of sufficiency (Table 4). These data for $\mathrm{K}$ are of high agronomic importance, since zeolite contains approximately $15,000 \mathrm{mg} \mathrm{kg}^{-1} \mathrm{~K}$ (Table 1); thus, it is a very good source of $\mathrm{K}$ for crop nutrition, which could substitute inorganic $\mathrm{K}$ fertilization inputs.

Apart from zeolite, goat manure was also a good source of $\mathrm{K}(2.54 \% \mathrm{dw})$, contributing to plant $\mathrm{K}$ nutrition, since together with zeolite, it had a strong synergistic action in boosting exchangeable $\mathrm{K}$ (it significantly increased soil $\mathrm{K}$ to $2433 \mathrm{mg} \mathrm{kg}^{-1}$ in the manure + zeo treatment, compared to $1613 \mathrm{mg}$ $\mathrm{kg}^{-1}$ in the zeo and $1062 \mathrm{mg} \mathrm{kg}^{-1}$ in the zeo + ver treatments, respectively) (Table 2). This synergistic action of zeolite with goat manure in boosting $\mathrm{K}$ uptake was clearly apparent in tomato fruit $\mathrm{K}$, since the highest $\mathrm{K}$ concentrations were found in the manure + zeo and zeo treatments $(5.30$ and $4.75 \% \mathrm{dw}$, respectively) (Table 6). Potassium was found to affect the qualitative fruit characteristics [50]; thus, it is quite reasonable to assume that with the suitable combinational fertilization with zeolite and goat manure, the optimum tomato fruit quality will be achieved; however, additional research (including also postharvest measurements for tomato fruits) should be included to verify this hypothesis. In the study of Glisic et al. [2], it was found that the combinational supply of zeolite with manure provided similar fruit quality characteristics (soluble solids, total acids) with the co-application of the inorganic fertilizer 15-15-15 and manure. Similarly, the co-application of the inorganic fertilizer 15-15-15, calcium ammonium nitrate, and natural zeolite induced the highest levels of total phenolics, flavonoid content, and total antioxidant capacity (qualitative characteristics) in apricot fruits [51]. Jami et al., [52] concluded that two years after fertilization with farmyard manure, linoleic and oleic acid contents 
were increased and the quality of sunflower seed oil was improved. With regard to $\mathrm{K}$ uptake by Solanum lycopersicon L. plants, significantly higher K content was found in the CRF, zeo, manure + zeo, and zeo + ver treatments, compared to the ver and manure + ver treatments (Figure 1C). These findings clearly show the beneficial role of zeolite to obtain similar beneficial results with inorganic fertilization in enhancing K uptake by Solanum lycopersicon L. plants.

After the application of zeo, and especially in co-application with manure, exchangeable Ca was significantly increased (2964 $\mathrm{mg} \mathrm{kg}^{-1}$ in the manure + zeo and $2550 \mathrm{mg} \mathrm{kg}^{-1}$ in the zeo treatment), compared to the control soil (1711 mg kg-1) (Table 2). This increase in exchangeable Ca led to an improvement in foliar $\mathrm{Ca}$, compared to the control (although the increase was nonsignificant in the manure + zeo treatment) (Table 5). A similar tendency was also found for total Ca content, which was significantly higher in the CRF, zeo, and manure + zeo, compared to the ver treatments (ver, zeo + ver, manure + ver) (Figure 1D). Foliar Ca concentrations varied from 2.66 to $3.86 \%$ dw (Table 5). Bergmann (1986) [49] quoted that leaf Ca sufficiency levels in tomato plants should vary from 3.0 to $4.0 \%$ dw. Based on this, foliar Ca in the CRF was below the optimum levels, while the zeo and ver treatments provided the best results. The highest fruit Ca concentrations were determined in the manure + ver $(0.23 \% \mathrm{dw})$ and zeo $(0.21 \% \mathrm{dw})$ treatments (Table 5), which probably shows the beneficial effects of zeo, ver, and goat manure in improving tomato fruit Ca and its quality, since Ca affects cell wall structure and fruit quality [50]. However, more research, including also postharvest measurements for tomato fruit qualitative characteristics, should be included in order to verify this hypothesis.

In contrast to the previous data for the role of zeo in boosting soil $\mathrm{K}$ and $\mathrm{Ca}$, zeo did not have an impressive boosting effect in $\mathrm{NO}_{3}-\mathrm{N}, \mathrm{NH}_{4}-\mathrm{N}$, and $\mathrm{P}$ (Table 2) because its nutritional effect, as a soil amendment, for $\mathrm{N}$ and $\mathrm{P}$ was low (zeo contained only $9.36 \mathrm{mg} \mathrm{kg}^{-1} \mathrm{~N}$ and $1.87 \mathrm{mg} \mathrm{kg}^{-1} \mathrm{P}$ ) (Table 1). $\mathrm{NO}_{3}-\mathrm{N}$ was impressively enhanced from 28 to 48 times only after manure application, compared to the control soil (Table 2). This beneficial role of goat manure in increasing $\mathrm{NO}_{3}-\mathrm{N}$ should be ascribed to the high $\mathrm{N}$ content of goat manure $(2.80 \% \mathrm{dw})$. Foliar $\mathrm{N}$ among the treatments varied from 3.42 to $4.83 \%$ dw (Table 5). According to Bergmann (1986) [49], the optimum $\mathrm{N}$ in tomato leaves should vary from 4.0 to $5.5 \%$ dw. Based on this reference, it should be pointed out that only the leaf $\mathrm{N}$ concentrations in the CRF and in the zeo + ver treatments (4.83 and $4.24 \% \mathrm{dw}$, respectively) were within the optimum range of sufficiency, while in all the other treatments, they were either marginal or insufficient.

At the end of the experiment, the highest total $\mathrm{N}$ content per plant was found in the CRF treatment (approximately $750 \mathrm{mg}$ ), while the lowest total quantities were determined in the manure treatments (approximately 100-200 mg) (Figure 1A). The fact that the lowest plant $\mathrm{N}$ contents were found in the manure treatments (manure + ver, manure + zeo), despite the high $\mathrm{NO}_{3}-\mathrm{N}$ levels existing in the amended soil (approximately 97 and $57 \mathrm{mg} \mathrm{kg}^{-1}$, respectively) (Table 2), could be possibly ascribed to the lower foliar, stem, and root $\mathrm{N}$ concentrations, as well as to the lower biomass of these tissues (Table 4). Another possible explanation of the low $\mathrm{N}$ content in the manure treatments might include the co-effect of intensified $\mathrm{N}$ microbial immobilization and/or heterotrophic (nitrification-coupled) denitrification processes, induced by the presence of organic $\mathrm{C}$ and high nitrate availability in the manure treatments $[53,54]$. However, this hypothesis needs further investigation in the near future. In line with the previous hypothesis, the controlled release fertilizer or the single/mixed vermiculite and zeolite treatments used in the present study might have prevented the creation of excessive nitrates, enhancing plant growth, while also minimizing the $\mathrm{N}$ loss via leaching or denitrification.

With regard to $\mathrm{P}$, the boosting effect of goat manure in soil $\mathrm{P}$, from 1.44 to approximately 24-27 $\mathrm{mg} \mathrm{kg}^{-1}$ after its application (Table 2), might be ascribed to the high $\mathrm{P}$ content of manure $(0.13 \% \mathrm{dw})$. Significantly higher P content was absorbed by the plants in the CRF treatment (approximately $230 \mathrm{mg}$ ), followed by the contents taken up by the plants in the manure treatments (approximately 180-190 mg) (Figure 1B). Thus, it seems that either CRF or manure application provided the most promising results with regard to P fertilization of the Solanum lycopersicon L. plants. However, in all the treatments, foliar P concentrations were high (Table 5), more than those quoted by Bergmann (1986) [49] to be within the optimum range $(0.40-0.65 \% \mathrm{dw})$. 
Iron content of vermiculite (14.44 $\mathrm{mg} \mathrm{kg}^{-1}$ ) was about 28 times higher to that of zeolite (only $0.57 \mathrm{mg} \mathrm{kg}^{-1}$ ) (Table 1). However, both were very low compared to the Fe concentration of goat manure $\left(1927 \mathrm{mg} \mathrm{kg}^{-1}\right)$, which seems to be a good source of Fe for plant nutrition. Similarly for Mn and Zn, goat manure was also a good source of these micronutrients, since their concentrations were high (367 and $81 \mathrm{mg} \mathrm{kg}^{-1}$ ), compared to the $\mathrm{Mn}$ and $\mathrm{Zn}$ concentrations of zeolite and vermiculite, which were low (1.12-1.92 and $0.24-0.33 \mathrm{mg} \mathrm{kg}^{-1}$, respectively) (Table 1). However, after manure application only, soil Zn concentrations were increased (approximately 5-6.5 times, compared to the control soil), while those of Fe and Mn were decreased (Table 3). This might be probably ascribed to the formation of stable Fe and Mn complexes with organic matter, which decreased Fe and Mn availability. In the study of Hamidpour et al., (2017) [4], who managed to decrease Cd and Zn availability with vermicompost and zeolite application in a contaminated soil, it was found that the reduced soil availability was accompanied by a transformation/redistribution of plant-available forms to organic matter and metal oxide-associated fractions [4]. Similarly for zeo and ver, their negative effect on soil Fe and Mn availability was clear after their application; especially for zeo, the most clear inhibitory effect was recorded on soil $\mathrm{Mn}$, where its availability was decreased by approximately $50 \%$ after zeo application, compared to the control soil (Table 3).

The highest $\mathrm{Fe}, \mathrm{Mn}$, and $\mathrm{Zn}$ accumulation was recorded in the CRF treatment, compared to the other ones (Figure 2A-C); in the case of $\mathrm{Mn}$, quite remarkable is the insignificant difference in total quantity recorded between the plants that received inorganic fertilization (CRF) and those that received only zeo (Figure 2B), while in the case of $\mathrm{Cu}$, the zeo-treated plants absorbed slightly higher $\mathrm{Cu}$ quantity, compared to those fertilized with CRF (Figure 2D). This probably means that zeo application could be an alternative fertilization strategy for micronutrients (especially for $\mathrm{Mn}$ and $\mathrm{Cu}$ and afterwards, for $\mathrm{Zn}$ ), being able to partially decrease the high chemical fertilization inputs in Solanum lycopersicon $\mathrm{L}$. crops. Indeed, previous studies have highlighted the potential role of zeolite to supply crops with micronutrients, such as $\mathrm{Mn}, \mathrm{Cu}$, and $\mathrm{Zn}[55,56]$. However, in our study, it seems that the beneficial role of zeolite in boosting plant $\mathrm{Mn}$ and $\mathrm{Cu}$ uptake by tomato plants was probably owed to the enhanced retention capacity of zeolite [57], which probably prevented micronutrients from leaching, rather than to supply tomato plants with $\mathrm{Mn}$ and $\mathrm{Cu}$, since both zeolite and vermiculite were poor in $\mathrm{Mn}$ and $\mathrm{Cu}$, compared to those of goat manure (Table 1). For Fe and Zn, an alternative fertilization strategy, which could partially decrease inorganic fertilization inputs, might constitute a single application of zeo/ver, or a co-application of zeo and ver (Table 5; Figure 2A,C). In the study of Najafi-Ghiri and Rahimi [58], it was found that application of zeolite and vermicompost significantly increased $\mathrm{Zn}$ uptake by spinach plants. According to Gholamhoseini et al. [20] and Khodaei-Joghan et al. [59], co-amending soil with manure and zeolite can be a beneficial approach for decreasing chemical fertilizer applications and improving the sustainability of agricultural systems. In addition, the co-application of a NPK fertilizer, cattle manure, and zeolite improved foliar micronutrient nutrition in apple trees [60].

With regard to the influence of soil amendments on plant growth, significantly lower dry weight of total plant biomass was found in the vermiculite treatments (ver, ver + manure), and manure + zeo, compared to the CRF (Table 4). Similarly to our results, Milosevic et al. [61] found that the combined application of manure and zeolite, as well as zeolite supply alone, induced the lowest blackberry growth and shoot bearing characteristics. In the ver and manure + zeo treatments of our experiment, total plant growth was negatively influenced by vermiculite and manure application, probably due to the low $\mathrm{N}$ uptake by plants that occurred in these cases (Figure 1A). Low N negatively influences plant growth and vegetation flush [62]. According to Boussadia et al. [63], the total biomass of two olive cultivars ("Meski" and "Koroneiki") was strongly reduced (mainly caused by a decrease in leaf $\mathrm{dw}$ ) under $\mathrm{N}$ deprivation, which confirms our results. In the study of Basri et al. [47], it was found that the highest kenaf growth was observed in a co-application of an inorganic NPK fertilizer, biochar, and zeolite, compared to the single application of biochar or zeolite [47]. The ratio leaf $+\mathrm{stem} / \mathrm{root}$ was significantly higher in the zeo treatments (zeo, zeo + ver, and manure + zeo), compared to the manure + ver, where the lowest value was recorded (6.24) (Table 4), which coincided with the lowest $\mathrm{N}$ 
content (Figure 1A) and the lowest foliar N concentration (3.42\% dw) (Table 5). Reddy and Matcha [64], who worked with Ricinus communis L. plants, found that the ratio shoot/root decreased under $\mathrm{N}$ deficiency, something which is also confirmed by our results.

Similarly to total plant biomass and the ratio shoot/root, the minimum mean fruit weights were also found in the manure + ver and ver treatments (Figure 3); these minimum values coincided with the minimum fruit $\mathrm{N}$ and $\mathrm{Zn}$ concentrations (Table 6). Low $\mathrm{Zn}$ concentrations are usually responsible for small leaf and fruit formation, since $\mathrm{Zn}$ plays a crucial role in IAA (auxin) synthesis (a direct influence of $\mathrm{Zn}$ on plant growth and biomass production); IAA concentration is significantly decreased in vegetative tissues with low $\mathrm{Zn}$ content [62]. The maximum mean fruit weight was recorded in the CRF, followed by the values in the zeo + ver and zeo treatments (Figure 3). Assimakopoulou et al. [19], who studied the growth, yield, and nutrient status of pepper plants grown on a soil substrate with olive mill waste (OMW) sludge $(0,2.5$, and $5 \%)$ and natural zeolite application $(0,2.5$, and $5 \%)$, found that the plants grown under $5 \%$ zeolite and $2.5 \%$ OMW showed higher fruit biomass, compared to the plants grown under $2.5 \%$ zeolite and $2.5 \%$ OMW; in contrast, when the plants were grown under $5 \% \mathrm{OMW}$, with whatever zeolite level, they produced the lowest yields [19]. In contrast, Litaor et al., (2017) [48] concluded that (i) compost application significantly increased potatoes' yield and the number of large tubers and (ii) zeolite addition had no impact on yield. Similarly, it was found that cattle manure application promoted the highest apricot fruit weight [51].

The influence of the kind of soil amendment on photosystem II activity was quite interesting. The optimum and significantly higher performance of PSII (as described by the parameters $\mathrm{F}_{\mathrm{v}} / \mathrm{F}_{\mathrm{m}}, \mathrm{F}_{\mathrm{v}} / \mathrm{F}_{0}$, and Performance Index) was recorded in the ver treatment, compared to the other ones; in contrast, the lowest PSII activity was found in the zeo and manure + ver treatments, for all the three parameters determined (Figure 4A-C). These differences in PSII activity among the treatments should be mainly ascribed to the differences in foliar Mn nutrition and to the optimum Mn level found in ver (138 $\left.\mathrm{mg} \mathrm{kg}^{1}\right)$ (Table 5). Manganese plays a key role in photosystem II of photosynthesis and particularly in the reactions liberating $\mathrm{O}_{2}$ [62].

\section{Conclusions}

In conclusion, single zeolite application (zeo), or in co-application with vermiculite (zeo + ver), provided, in some cases, better or similar (or slightly lower) beneficial results to those obtained with CRF (especially in foliar $\mathrm{K}, \mathrm{Ca}$, and $\mathrm{Zn}$ nutrition; $\mathrm{K}, \mathrm{Ca}, \mathrm{N}, \mathrm{Mn}, \mathrm{Zn}$, and $\mathrm{Cu}$ accumulation; mean fruit weight; fruit $\mathrm{K}, \mathrm{Zn}$, and $\mathrm{N}$ concentrations). In contrast, the combinational application of zeolite/vermiculite with manure did not provide promising results with regard to total biomass, fruit weight, most nutrients' uptake (with the exception of P uptake), and PSII activity. Yield of PSII was significantly higher in ver, compared to the other treatments, and this was probably owed to the optimum foliar Mn $\left(138 \mathrm{mg} \mathrm{kg}^{-1}\right)$. The CRF provided the best effects on plant growth, $\mathrm{N}$ uptake (probably due to low rate release of $\mathrm{N}$ ), and fruit weight. In addition, fruit qualitative characteristics should be measured to test if enhanced foliar $\mathrm{K}$ and Ca nutrition obtained in the zeo treatments is accompanied by high tomato fruit quality. It is believed that these data will provide a useful tool towards decreasing chemical fertilization inputs and improving the sustainability of Solanum lycopersicon L. crops.

Author Contributions: Conceptualization, T.C.; methodology, T.C., V.T. and P.P.; software, T.C.; validation, T.C. and V.T.; formal analysis, T.C.; investigation, T.C., V.T. and A.G.; resources, T.C.; data curation, T.C., A.G. and P.P.; writing - original draft preparation, T.C.; writing—review and editing, T.C. and V.T.; visualization, T.C.; supervision, T.C.; project administration, T.C. All authors have read and agreed to the published version of the manuscript.

Funding: This research received no external funding.

Acknowledgments: We would like to thank the company NORDIA A.E. for providing us with their commercial products of zeolite and vermiculite.

Conflicts of Interest: The authors declare no conflict of interest. 


\section{References}

1. Eprikashvili, L.; Zautashvili, M.; Kordzakhia, T.; Pirtskhalava, N.; Dzagania, M.; Rubashvili, I.; Tsitsishvili, V. Intensification of bio-productivity of agricultural cultures by adding natural zeolites and brown coals into soils. Ann. Agrar. Sci. 2016, 14, 67-71. [CrossRef]

2. Glisic, I.P.; Milosevic, T.M.; Glisic, I.S.; Milosevic, N.T. The effect of natural zeolites and organic fertilizers on the characteristics of degraded soils and yield of crops grown in western Serbia. Land Degrad. Dev. 2009, 20, 33-40. [CrossRef]

3. Malandrino, M.; Abollino, O.; Buoso, S.; Giacomino, A.; La Gioia, C.; Mentasti, E. Accumulation of heavy metals from contaminated soil to plants and evaluation of soil remediation by vermiculite. Chemosphere 2011, 82, 169-178. [CrossRef] [PubMed]

4. Hamidpour, M.; Akbari, L.; Shirani, H. Effects of co-application of zeolites and vermicompost on speciation and phytoavailability of cadmium, lead and zinc in a contaminated soil. Commun. Soil Sci. Plant Anal. 2017, 48, 262-273. [CrossRef]

5. Doostikhah, N.; Panahpour, E.; Nadian, H.; Gholami, A. Tomato (Lycopersicon esculentum L.) nutrient and lead uptake affected by zeolite and DTPA in a lead-polluted soil. Plant Biol. 2019, in press. [CrossRef] [PubMed]

6. Zhang, J.; Jiang, X.; Miao, Q.; Yu, B.; Xu, L.; Cui, Z. Combining mineral amendments improves wheat yield and soil properties in a coastal saline area. Agronomy 2019, 9, 48. [CrossRef]

7. Hamid, Y.; Tang, L.; Hussain, B.; Usman, M.; Rehman Hashmi, M.L.; Khan, M.B.; Yang, X.; He, Z. Immobilization and sorption of $\mathrm{Cd}$ and $\mathrm{Pb}$ in contaminated stagnic anthrosols as amended with biochar and manure combined with inorganic additives. J. Environ. Manag. 2020, 257, 109999. [CrossRef]

8. Baninasab, B. Effects of the application of natural zeolite on the growth and nutrient status of radish (Raphanus sativus L.). J. Hortic. Sci. Biotech. 2009, 84, 13-16. [CrossRef]

9. Paskovic, I.; Bronic, J.; Subotic, B.; Pecina, M.; Perica, S.; Palcic, I.; Herak Custic, M. Impact of zeolite fertilization on radicchio mineral composition and nutritive value. J. Food Agric. Environ. 2013, 11, 498-502.

10. Malekian, R.; Abedi-Koupai, J.; Eslamian, S.S. Influences of clinoptilolite and surfactant-modified clinoptilolite zeolite on nitrate leaching and plant growth. J. Hazard. Mater. 2011, 185, 970-976. [CrossRef]

11. Bybordi, A.; Ebrahimian, E. Growth, Yield and Quality Components of Canola Fertilized with Urea and Zeolite. Commun. Soil Sci. Plant Anal. 2013, 44, 2896-2915. [CrossRef]

12. Sun, Y.; Xia, G.; He, Z.; Wu, Q.; Zheng, J.; Li, Y.; Wang, Y.; Chen, T.; Chi, D. Zeolite amendment coupled with alternate wetting and drying to reduce nitrogen loss and enhance rice production. Field Crops Res. 2019, 235, 95-103. [CrossRef]

13. De Campos Bernardi, A.C.; Polidoro, J.C.; De Melo Monte, M.B.; Pereira, E.I.; De Oliveira, C.R.; Ramesh, K. Enhancing Nutrient Use Efficiency Using Zeolites Minerals-A Review. Adv. Chem. Eng. Sci. 2016, 6, 295-304. [CrossRef]

14. Mehrab, N.; Chorom, M.; Hojati, S. Effect of raw and $\mathrm{NH}_{4}{ }^{+}$-enriched zeolite on nitrogen uptake by wheat and nitrogen leaching in soils with different textures. Commun. Soil Sci. Plant Anal. 2016, 47, 1306-1316. [CrossRef]

15. Omar, L.; Ahmed, O.H.; Majid, N.M.A. Improving ammonium and nitrate release from urea using clinoptilolite zeolite and compost produced from agricultural wastes. Sci. World J. 2015, 2015, 574201. [CrossRef]

16. Zaman, M.; Nguyen, M. Effect of lime or zeolite on $\mathrm{N}_{2} \mathrm{O}$ and $\mathrm{N}_{2}$ emissions from a pastoral soil treated with urine or nitrate-N fertilizer under field conditions. Agric. Ecosyst. Environ. 2010, 136, 254-261. [CrossRef]

17. Ramesh, K.; Reddy, D.D. Zeolites and Their Potential Uses in Agriculture. In Advances in Agronomy; Sparks, D.L., Ed.; Academic Press: Cambridge, MA, USA, 2011; pp. 219-241.

18. Moraetis, D.; Papagiannidou, S.; Pratikakis, A.; Pentari, D.; Komnitsas, K. Effect of zeolite application on potassium release in sandy soils amended with municipal compost. Desalin. Water Treat. 2016, 57, 13273-13284. [CrossRef]

19. Assimakopoulou, A.; Dimitroulia, D.; Kosmidis, S.; Doula, M.K. Growth, yield and nutrient status of pepper plants grown on a soil substrate with olive mill waste sludge and natural zeolite addition. J. Plant Nutr. 2020, 43, 629-640. [CrossRef]

20. Gholamhoseini, M.; Ghalavand, A.; Khodaei-Joghan, A.; Dolatabadian, A.; Zakikhani, H.; Farmanbar, E. Zeolite-amended cattle manure effects on sunflower yield, seed quality, water use efficiency and nutrient leaching. Soil Til. Res. 2013, 126, 193-202. [CrossRef] 
21. Eroglu, N.; Emekci, M.; Athanassiou, C.G. Applications of natural zeolites on agriculture and food production. J. Sci. Food Agric. 2017, 97, 3487-3499. [CrossRef]

22. Prisa, D. Italian chabazitic-zeolitite and effective microorganisms for the qualitative improvement of olive trees. Arti Soc. Toscana Sci. Nat. Mem. Ser. B 2018, 125, 13-17.

23. Roosta, H.R.; Manzari Tavakkoli, M.; Hamidpour, M. Comparison of different soilless media for growing gerbera under alkalinity stress condition. J. Plant Nutr. 2016, 39, 1063-1073. [CrossRef]

24. Malamis, S.; Katsou, E. A review on zinc and nickel adsorption on natural and modified zeolite, bentonite and vermiculite: Examination of process parameters, kinetics and isotherms. J. Hazard. Mater. 2013, 252-253, 428-461. [CrossRef]

25. Mazloomi, F.; Jalali, M. Effects of vermiculite, nanoclay and zeolite on ammonium transport through saturated sandy loam soil: Column experiments and modeling approaches. Catena 2019, 176, 170-180. [CrossRef]

26. Pratt, C.; Redding, M.; Hill, J.; Brown, G.; Westermann, M. Clays can decrease gaseous nutrient losses from soil-applied livestock manures. J. Environ. Qual. 2016, 45, 638-645. [CrossRef] [PubMed]

27. He, Z.; Lin, H.; Hao, J.; Kong, X.; Tian, K.; Bei, Z.; Tian, X. Impact of vermiculite on ammonia emissions and organic matter decomposition of food waste during composting. Biores. Technol. 2018, 263, 548-554. [CrossRef]

28. Aainaa, H.N.; Ahmed, O.H.; Ab Majid, N.M. Effects of clinoptilolite zeolite on phosphorus dynamics and yield of Zea mays L. cultivated on an acid soil. PLoS ONE 2018, 13, e0204401.

29. Goloran, J.B.; Phillips, I.R.; Xu, Z.H.; Condron, L.M.; Chen, C.R. Effects of amendments and fertilization on plant growth, nitrogen and phosphorus availability in rehabilitated highly alkaline bauxite-processing residue sand. Soil Use Manag. 2014, 30, 198-208. [CrossRef]

30. Kocaturk-Schumacher, N.P.; Zwart, K.; Bruun, S.; Jensen, L.S.; Sorensen, H.; Brussaard, L. Recovery of nutrients from the liquid fraction of digestate: Use of enriched zeolite and biochar as nitrogen fertilizers. J. Plant Nutr. Soil Sci. 2019, 182, 187-195. [CrossRef]

31. Paskovic, I.; Pecina, M.; Bronic, J.; Perica, S.; Ban, D.; Goreta Ban, S.; Poscic, F.; Palcic, I.; Herak Custic, M. Synthetic zeolite A as zinc and manganese fertilizer in calcareous soil. Commun. Soil Sci. Plant Anal. 2018. [CrossRef]

32. Abdel-Fattah, M.K.; Merwad, A. Effect of different sources of nitrogen fertilizers combined with vermiculite on productivity of wheat and availability of nitrogen in sandy soil in Egypt. Am. J. Plant Nutr. Fertil. Technol. 2015, 5, 50-60. [CrossRef]

33. Merwad, A.R.; Awad, E.A.M.; Mohamed, I.R.; Dahdouh, S.M.M. Effect of some phosphatic fertilizers and soil amendments on the availability of phosphorus in soil. Zagazig J. Agric. Res. 2013, 40, 483-494.

34. Chatzistathis, T.; Papadakis, I.E.; Papaioannou, A.; Chatzissavvidis, C.; Giannakoula, A. Comparative study effects between manure application and a controlled release fertilizer on the growth, nutrient uptake, photosystem II activity and photosynthetic rate of Olea europaea L. (cv. 'Koroneiki'). Sci. Hortic. 2020, 264, 109176. [CrossRef]

35. McLean, E. Soil pH and lime requirement. In Methods of Soil Analysis, Part 2: Chemical and Microbiological Properties; Page, A.L., Miller, R.H., Keeney, D.R., Eds.; Agronomy Monograph, ASA, SSSA: Madison, WI, USA, 1982; pp. 199-224.

36. Gee, G.; Bauder, J. Particle-size analysis. In Methods of Soil Analysis, Part 1: Physical and Mineralogical Methods; Klute, A., Ed.; ASA, SSSA: Madison, WI, USA, 1986; pp. 383-411.

37. Nelson, D.W.; Sommers, L.E. Total carbon, organic carbon and organic matter. In Methods of Soil Analysis, Part 2: Chemical and Microbiological Properties; Page, A.L., Miller, R.H., Keeney, D.R., Eds.; Agronomy Monograph, ASA, SSSA: Madison, WI, USA, 1982; pp. 539-547.

38. Hood-Nowotny, R.; Umana, N.H.-N.; Inselbacher, E.; Oswald- Lachouani, P.; Wanek, W. Alternative Methods for Measuring Inorganic, Organic, and Total Dissolved Nitrogen. Soil Sci. Soc. Am. J. 2010, 74, 1018-1027. [CrossRef]

39. Mulvaney, R. Nitrogen-Inorganic Forms. In Methods of Soil Analysis: Part 3 Chemical Methods 5; ASA, SSSA: Madison, WI, USA, 1996; pp. 1123-1184.

40. Olsen, S.; Sommers, L. Phosphorus. In Agronomy Monograph, Methods of Soil Analysis, Part 2: Chemical and Microbiological Properties; Page, A.L., Miller, R.H., Keeney, D.R., Eds.; ASA, SSSA: Madison, WI, USA, 1982; pp. 403-430. 
41. Thomas, G.W. Exchangeable cations. Methods of soil analysis. In Agronomy Monograph, Methods of Soil Analysis, Part 2: Chemical and Microbiological Properties; Page, A.L., Miller, R.H., Keeney, D.R., Eds.; ASA, SSSA: Madison, WI, USA, 1982; pp. 159-166.

42. Lindsay, W.L.; Norvell, W.A. Development of a DTPA soil test for zinc, iron, manganese, and copper. Soil Sci. Soc. Am. J. 1978, 42, 421-428. [CrossRef]

43. Chyla, M.A.; Żyrnicki, W. Determination of metal concentrations in animal hair by the ICP method Biological. Biol. Trace Elem. Res. 2000, 75, 187-194. [CrossRef]

44. Chapman, H.D.; Pratt, P.F. Methods of Analysis for Soils, Plants and Waters; Division of Agricultural Sciences, University of California: Riverside, CA, USA, 1961; p. 309.

45. Strasser, R.J.; Tsimilli-Michael, M.; Srivastava, A. Analysis of the chlorophyll a fluorescence transient. In Chlorophyll a Fluorescence: A Signature of Photosynthesis; Papageorgiou, G.C., Govindjee, C., Eds.; Springer: Dordrecht, The Netherlands, 2004; pp. 321-362.

46. Schreiber, U.; Schliwa, U.; Bilger, W. Continuous recording of photochemical and non-photochemical chlorophyll fluorescence quenching with a new type of modulation fluorometer. Photosynth. Res. 1986, 10, 51-62. [CrossRef]

47. Basri, M.H.; Abdu, A.; Jusop, S.; Ahmed, O.H.; Abdul-Hamid, H.; Kusno, M.A.; Zainal, B.; Senin, A.L.; Junejo, N. Effects of mixed organic and inorganic fertilizers application on soil properties and the growth of Kenaf (Hibiscus cannabinus L.) cultivated on Bris soils. Am. J. Appl. Sci. 2013, 10, 1586-1597. [CrossRef]

48. Litaor, M.I.; Katz, L.; Shenker, M. The influence of compost and zeolite co-addition on the nutrients' status and plant growth in intensively cultivated Mediterranean soils. Soil Use Manag. 2017, 33, 72-80. [CrossRef]

49. Bergmann, W. Ernahrungstorungen bei Kulturpflanzen; Gustav Fischer Verlag: Stuttgart, Germany, 1986.

50. Therios, I. Mineral Nutrition of Plants; Dedousi Publications: Thessaloniki, Greece, 1996. (In Greek)

51. Milosevic, T.; Milosevic, N.; Glisic, I.; Boskovic-Rakosevic, L.; Milivojevic, J. Fertilization effect on trees and fruits characteristics and leaf nutrient status of apricots which are grown at Cacak region (Serbia). Sci. Hortic. 2013, 164, 112-123. [CrossRef]

52. Jami, M.G.; Baghbani-Arani, A.; Borz-Abad, R.K.; Saadathah, A. Towards improving the vegetative and qualitative traits of sunflower using amending soil (zeolite and manure fermyard) under water deficit stress. Commun. Soil Sci. Plant Anal. 2019, 50, 2227-2237. [CrossRef]

53. Burger, M.; Jackson, L.E. Microbial immobilization of ammonium and nitrate in relation to ammonification and nitrification rates in organic and conventional cropping systems. Soil Biol. Biochem. 2003, 35, $29-36$. [CrossRef]

54. Calderón, F.J.; McCarty, G.W.; Van Kessel, J.A.S.; Reeves, J.B. Carbon and Nitrogen Dynamics during Incubation of Manured Soil. Soil Sci. Soc. Am. J. 2004, 68, 1592-1599. [CrossRef]

55. Mahmoodabadi, M.R.; Ronaghi, A.M.; Khayyat, M.; Hadarbadi, G. Effects of zeolite and cadmium on growth and chemical composition of soybean (Glycine max L.). Trop. Subtrop. Agroecosyst. 2009, 10, 515-521.

56. Ozbahce, A.; Tari, A.F.; Gönülal, E.; Simsekli, N.; Padem, H. The effect of zeolite applications on yield components and nutrient uptake of common bean under water stress. Arch. Agron. Soil Sci. 2015, 61, 615-626. [CrossRef]

57. Iskander, A.L.; Khald, E.M.; Sheta, A.S. Zinc and manganese sorption behavior by natural zeolite and bentonite. Ann. Agric. Sci. 2011, 56, 43-48. [CrossRef]

58. Najafi-Ghiri, M.; Rahimi, T. Zinc uptake by spinach (Spinacia oleracea L.) as affected by Zn application rate, zeolite and vermicompost. Compost Sci. Util. 2016, 24, 203-207. [CrossRef]

59. Khodaei-Joghan, A.; Gholamhoseini, M.; Agha-Alikhani, M.; Habibzadeh, F.; Sorooshzadeh, A.; Ghalavand, A. Response of sunflower to organic and chemical fertilizers in different drought stress conditions. Acta Agric. Slov. 2018, 111, 271-284. [CrossRef]

60. Milosevic, T.; Milosevic, N. Influence of mineral fertilizer, farmyard manure, natural zeolite and their mixture on fruit quality and leaf micronutrient levels of apple trees. Commun. Soil Sci. Plant Anal. 2017, 48, 539-548. [CrossRef]

61. Milosevic, T.M.; Glisic, I.P.; Glisic, I.S.; Milosevic, N.T. Cane properties, yield berry quality attributes and leaf nutrient composition of blackberry as affected by different fertilization regimes. Sci. Hortic. 2018, 227, 48-56. [CrossRef] 
62. Chatzistathis, T.; Therios, I. How soil nutrient availability influences plant biomass and how biomass stimulation alleviates heavy metal toxicity in soils: The cases of nutrient use efficient genotypes and phytoremediators, respectively. In Biomass Now-Cultivation and Utilization; Matovic, D.M., Ed.; IntechOpen: Rijeka, Croatia, 2013; pp. 427-448, ISBN 978-953-51-1106-1. [CrossRef]

63. Boussadia, O.; Steppe, K.; Zgallai, H.; El Hadj, S.B.; Braham, M.; Lemeur, M.; Van Labeke, M.C. Effects of nitrogen efficiency on leaf photosynthesis, carbohydrate status and biomass production in two olive cultivars ('Meski' and 'Koroneiki'). Sci. Hortic. 2010, 123, 336-342. [CrossRef]

64. Reddy, K.R.; Matcha, S.K. Quantifying nitrogen effects on castor bean (Ricinus communis L.) development, growth and photosynthesis. Ind. Crops Prod. 2010, 31, 185-191. [CrossRef]

Publisher's Note: MDPI stays neutral with regard to jurisdictional claims in published maps and institutional affiliations.

(C) 2020 by the authors. Licensee MDPI, Basel, Switzerland. This article is an open access article distributed under the terms and conditions of the Creative Commons Attribution (CC BY) license (http://creativecommons.org/licenses/by/4.0/). 